University of New Hampshire

University of New Hampshire Scholars' Repository

6-20-1996

\title{
Modeling of the processing and removal of trace gas and aerosol species by Arctic radiation fogs and comparison with measurements
}

\author{
$\mathrm{MH}$. Bergin \\ Carnegie Mellon University \\ S N. Pandis \\ Carnegie Mellon University \\ C Davidson \\ Carnegie Mellon University \\ J L. Jaffrezo \\ Domaine Universitaire, Grenoble, Franc \\ Jack E. Dibb \\ University of New Hampshire, jack.dibb@unh.edu
}

See next page for additional authors

Follow this and additional works at: https://scholars.unh.edu/earthsci_facpub

Part of the Atmospheric Sciences Commons

\section{Recommended Citation}

Bergin, M. H., S. N. Pandis, C. I. Davidson, J.-L. Jaffrezo, J. E. Dibb, A. G. Russell, and H. D. Kuhns (1996), Modeling of the processing and removal of trace gas and aerosol species by Arctic radiation fogs and comparison with measurements, J. Geophys. Res., 101(D9), 14465-14478, doi:10.1029/96JD00340.

This Article is brought to you for free and open access by the Earth Sciences at University of New Hampshire Scholars' Repository. It has been accepted for inclusion in Earth Sciences Scholarship by an authorized administrator of University of New Hampshire Scholars' Repository. For more information, please contact Scholarly.Communication@unh.edu. 


\section{Authors}

M H. Bergin, S N. Pandis, C Davidson, J L. Jaffrezo, Jack E. Dibb, A G. Russell, and H D. Kuhns 


\title{
Modeling of the processing and removal of trace gas and aerosol species by Arctic radiation fogs and comparison with measurements
}

\author{
M.H. Bergin, ${ }^{1,2}$ S.N. Pandis, ${ }^{3}$ C.I. Davidson, ${ }^{4}$ J.-L. Jaffrezo, ${ }^{5}$ J.E. Dibb, ${ }^{6}$ \\ A. G. Russell, ${ }^{7,8}$ and H.D. Kuhns ${ }^{1}$
}

\begin{abstract}
A Lagrangian radiation fog model is applied to a fog event at Summit, Greenland. The model simulates the formation and dissipation of fog. Included in the model are detailed gas and aqueous phase chemistry, and deposition of chemical species with fog droplets. Model predictions of the gas phase concentrations of $\mathrm{H}_{2} \mathrm{O}_{2}, \mathrm{HCOOH}, \mathrm{SO}_{2}$, and $\mathrm{HNO}_{3}$ as well as the fog fluxes of $\mathrm{S}(\mathrm{VI}), \mathrm{N}(\mathrm{V}), \mathrm{H}_{2} \mathrm{O}_{2}$, and water are compared with measurements. The predicted fluxes of $\mathrm{S}(\mathrm{VI}), \mathrm{N}(\mathrm{V}), \mathrm{H}_{2} \mathrm{O}_{2}$, and fog water generally agree with measured values. Model results show that heterogeneous $\mathrm{SO}_{2}$ oxidation contributes to approximately $40 \%$ of the flux of S(VI) for the modeled fog event, with the other $60 \%$ coming from preexisting sulfate aerosol. The deposition of $\mathrm{N}(\mathrm{V})$ with fog includes contributions from $\mathrm{HNO}_{3}$ and $\mathrm{NO}_{2}$ initially present in the air mass. $\mathrm{HNO}_{3}$ directly partitions into the aqueous phase to create $\mathrm{N}(\mathrm{V})$, and $\mathrm{NO}_{2}$ forms $\mathrm{N}(\mathrm{V})$ through reaction with $\mathrm{OH}$ and the nighttime chemistry set of reactions which involves $\mathrm{N}_{2} \mathrm{O}_{5}$ and water vapor. PAN contributes to $\mathrm{N}(\mathrm{V})$ by gas phase decomposition to $\mathrm{NO}_{2}$, and also by direct aqueous phase decomposition. The quantitative contributions from each path are uncertain since direct measurements of PAN and $\mathrm{NO}_{2}$ are not available for the fog event. The relative contributions are discussed based on realistic ranges of atmospheric concentrations. Model results suggest that in addition to the aqueous phase partitioning of the initial $\mathrm{HNO}_{3}$ present in the air mass, the gas phase decomposition of PAN and subsequent reactions of $\mathrm{NO}_{2}$ with $\mathrm{OH}$ as well as nighttime nitrate chemistry may play significant roles in depositing $N(V)$ with fog. If a quasi-liquid layer exists on snow crystals, it is possible that the reactions taking place in fog droplets also occur to some extent in clouds as well as at the snow surface.
\end{abstract}

\section{Introduction}

Ice cores recently retrieved at Summit, central Greenland, by groups from Europe (GRIP) and the United States (GISP2) potentially contain a record of atmospheric chemistry over approximately the last 250,000 years [Dansgaard et al., 1993; Mayewski et al., 1994]. The chemical composition of these ice cores includes species that originated as aerosols, as well as soluble gases. The main processes that deposit these species

\footnotetext{
Department of Civil and Environmental Engineering, Carnegie Mellon University, Pittsburgh, Pennsylvania.

${ }^{2}$ Now at Climate Monitoring and Diagnostics Laboratory, National Oceanic and Atmospheric Administration, Boulder, Colorado.

${ }^{3}$ Department of Chemical Engineering and Engineering and Public Policy, Carnegie Mellon University, Pittsburgh, Pennsylvania.

${ }^{4}$ Department of Civil and Environmental Engineering and Engineering and Public Policy, Carnegic Mellon University, Pittsburgh, Pennsylvania.

${ }^{5}$ Laboratoire de Glaciologie et Géophysique de l'Environnement du CRNS, Saint Martin d'Héres, France.

${ }^{6}$ Institute for the study of Earth, Oceans, and Space, University of New Hampshire, Durham, New Hampshire.

${ }^{7}$ Department of Mechanical Engineering. Carnegie Mellon University, Pittsburgh, Pennsylvania.

sow at School of Civil and Environmental Engineering, Georgia lnstitute of Technology, Allanta, Georgia.
}

Copyright 1996 by the American Geophysical Union.

Paper number 96JD00340.

0148-0227/96/96JD-00340\$09.00 onto the ice sheet are snow, fog, and dry deposition [Bergin et al., 1994; Davidson et al., 1996]. Recent work at Summit has shown that fog deposition of aerosol chemical species may contribute as much as one third to the chemical inventory in the summer snow layer and that deposition of soluble gases with fog may also be significant [Bergin et al., 1995a, b; Dibb et al., 1994].

The aerosol mass in summer at Summit is primarily dominated by sulfate (associated with various amounts of $\mathrm{NH}_{4}^{+}$) with lesser contributions from chemical species including methanesulfonic acid (MSA), $\mathrm{Na}^{+}$, and $\mathrm{Ca}^{2+}$ [Bergin et al., 1995b]. Important components of the atmospheric gaseous fraction which have been identified include the carboxylic acid formate $(\mathrm{HCOOH}), \mathrm{SO}_{2}, \mathrm{HNO}_{3}$ [Dibb et al., 1994], NOy (J.W. Munger, personal communication 1995), $\mathrm{H}_{2} \mathrm{O}_{2}$ [Bales et al., 1995a, b], and HCHO (K. Fuhrer, personal communication 1995). All of these chemical species are involved in fog cycles either as condensation nuclei or as soluble gases dissolved in fog droplets. These chemical species are also reflected in ice core samples and used as potential tracers for sources and/or atmospheric processes in the reconstruction of past climatic conditions. If accurate estimates of past atmospheric concentrations of aerosols and soluble gases are to be made based on signals in the recently retrieved ice cores, it is important to better understand the relationship among fogs, 
atmospheric chemistry, and the process of deposition of chemical species with fog in Greenland [Bergin et al., 1995c]. It is particularly important to understand the extent to which fogs have influenced the chemical signals archived in ice cores.

Sulfate and nitrate are the dominant ionic species in ice core samples from Greenland and have both anthropogenic and natural sources [Mayewski et al., 1990]. Based on several measurements made during the summer at Summit, Dibb et al. [1994] suggest that $\mathrm{SO}_{2}$ concentrations are typically 20 $\mathrm{ppt}$, with ratios of $\mathrm{SO}_{2}$ to aerosol sulfate of approximately one third. $\mathrm{H}_{2} \mathrm{O}_{2}$ concentrations are typically around $1 \mathrm{ppb}$ [Bales et al., 1995], which suggests that aqueous phase oxidation of $\mathrm{S}(\mathrm{IV})$ to $\mathrm{S}(\mathrm{VI})$ by $\mathrm{H}_{2} \mathrm{O}_{2}$ may account for a significant fraction of the S(VI) deposition during fog. Measurements of gas phase nitrogen-containing species at Summit show that $\mathrm{HNO}_{3}$ is typically less than $10 \%$ of the total $\mathrm{NO}_{\mathrm{y}}$. These measurements suggest that other nitrogen-containing species (such as PAN) may influence the deposition of $N(V)$ with fog droplets via gas and/or aqueous phase reactions. This paper will address these issues and discuss the chemical processes that affect the deposition of $\mathrm{N}(\mathrm{V})$ and $\mathrm{S}(\mathrm{VI})$ with fog. In particular, we will focus on the following questions: (1) How does $\mathrm{SO}_{2}$ influence the deposition of S(VI) with fog? (2) What role do the initial concentrations of $\mathrm{HNO}_{3}, \mathrm{NO}_{2}$, and PAN play in the deposition of $N(V)$ with fog? In addition, we will study the detailed gas and aqueous phase chemistry associated with $\mathrm{S}(\mathrm{VI})$ and $\mathrm{N}(\mathrm{V})$ deposition with fog.

Depletion of atmospheric concentrations of aerosols and soluble gases and enhancement of the deposition of various chemical species with fog has previously been shown for areas such as Southem California [Pandis and Seinfeld, 1989a; Munger et al., 1990] and the Po valley [Fuzzi et al., 1988; Noone et al., 1992]. These studies have shown that complex chemistry takes place in fog droplets and is responsible for the production and redistribution of chemical species between gases and aerosols.

Summit, Greenland, provides a unique opportunity to study fog formation and chemistry. Several experiments have been performed during the last several years as part of the GISP2 atmospheric sampling program (ATM) [Jaffrezo et al., 1995; Dibb et al., 1996] that include measurements of parameters related to the deposition of chemical species with fog, such as micrometeorological parameters, gas and aerosol concentrations, and fog droplet chemistry. The data serve as inputs and verification for the fog model presented in this paper. The modeling of fogs at Summit is simplified since the location is essentially flat with as many as $\mathbf{1 7}$ radiative fogs occurring in a summer month, typically lasting for several hours. The wind speeds during these fogs are relatively low (< $3 \mathrm{~m} / \mathrm{s}$ ) and the mixing with air aloft is generally restricted. The fluxes from the surface snow are apparently minor during fog events for many of the chemical species which simplifies the modeling of fogs since emission inventories are not needed [Bergin et al., 1994].

In this paper the fog model of Pandis and Seinfeld [1989a] is modified for conditions at Summit. The model is used to better understand the relationship between the concentrations of gas and aerosol chemical species and the deposition of these species with fog at Summit. The model is also used to interpret measurements of soluble gas phase chemical species. In particular, the model gives insight into the effects of local meteorology, aqueous phase solubility of gases, and gas and aqueous phase chemistry on the deposition of chemical species with fog, as well as gas and aqueous phase reactions affecting fog droplet chemistry, which may also occur in the quasi-liquid layer of snow crystals.

First, the model is presented with a brief description of important parameterizations and boundary conditions. Next, model results are compared with soluble gas phase concentration measurements made during a fog event. Following this, predicted fluxes of chemical species with fog are compared with measurements. Next, the effect of $\mathrm{SO}_{2}$ on the deposition of $\mathrm{S}(\mathrm{VI})$ is discussed. After this, the gas and aqueous phase chemistry influencing the deposition of $\mathrm{N}(\mathrm{V})$ with fog is discussed. Next, the sensitivity of the model to various input parameters is presented. Finally, the impact of the model results on the interpretation of past atmospheric chemistry based on ice core chemical signals is discussed.

\section{Model Description}

\section{Fog Module}

A one-dimensional Lagrangian trajectory model is used to simulate the development, growth, and dissipation of fog. The model consists of three submodels for the formation and dissipation of fog, gas phase chemistry, and aqueous phase chemistry, which estimate the time-resolved vertical profiles of temperature, relative humidity, and liquid water content as well as gas and aqueous phase chemical species.

The governing equations for the radiation fog model are the one-dimensional continuity equations for energy in the air (equation (1)) and snow (equation (2)) as well as for water vapor (equation (3)) and liquid water (equation (4)) in the air [Pandis and Seinfeld, 1989a]:

$$
\begin{aligned}
& \frac{\partial T}{\partial t}=-\frac{1}{\rho c_{p}} \frac{\partial F_{r}}{\partial z}+\frac{\partial}{\partial z}\left[K_{h}\left(\frac{\partial T}{\partial z}+\Gamma\right)\right]+\frac{L}{\rho c_{p}} C \\
& \frac{\partial T_{s}}{\partial t}=K_{s} \frac{\partial^{2} T_{s}}{\partial z^{2}} \\
& \frac{\partial q}{\partial t}=\frac{\partial}{\partial z}\left(K_{q} \frac{\partial q}{\partial z}\right)-C \\
& \frac{\partial w}{\partial t}=\frac{\partial}{\partial z}\left(K_{w} \frac{\partial w}{\partial z}\right)+\frac{\partial G}{\partial z}+C
\end{aligned}
$$

where $T$ is the air temperature $(\mathrm{K}), \rho$ the density of air $\left(\mathrm{g} / \mathrm{m}^{3}\right)$, $F_{r}$ the net radiation flux $\left(\mathrm{W} / \mathrm{m}^{2}\right), \Gamma$ the adiabatic lapse rate 
$(\mathrm{K} / \mathrm{m}), c_{p}$ the specific heat of air $(\mathrm{J} / \mathrm{g} \mathrm{K}), L$ the latent heat of vaporization of water $(\mathrm{J} / \mathrm{g}$ water), $C$ the water condensation rate $\left(\mathrm{g} / \mathrm{m}^{3} \mathrm{~s}\right), T_{s}$ the snow temperature $(\mathrm{K}), q$ the water vapor concentration $\left(\mathrm{g} / \mathrm{m}^{3}\right), w$ the liquid water concentration $\left(\mathrm{g} / \mathrm{m}^{3}\right)$, $G$ the liquid water gravitational flux $\left(\mathrm{g} / \mathrm{m}^{2} \mathrm{~s}\right), K_{h}, K_{q}$, and $K_{w}$ the exchange coefficients for heat, water vapor, and liquid water $\left(\mathrm{m}^{2} / \mathrm{s}\right)$, and $K_{s}$ the thermal conductivity of snow $(\mathrm{W} / \mathrm{m})$.

The system of partial differential equations is solved for 65 grid cells of varied size starting at $1 \mathrm{~m}$ below the snow surface and up to $400 \mathrm{~m}$ above the snow surface. Equations (1), (3), and (4) are solved from the ground surface to $400 \mathrm{~m}$, while equation (2) is solved from the surface to $1 \mathrm{~m}$ below the snow surface. Thirteen variable size grid cells are used inside the snow and 52 in the atmosphere.

The radiation flux, $F_{r}$ is calculated using the radiation model of Zdunkowski et al. [1982]. The radiation scheme accounts for the effects of gases, particles, clouds, and fog droplets on the radiation flux. The radiation grid contains $\mathbf{7 4}$ cells extending from the ground to $50 \mathrm{~km}$.

The exchange coefficients for heat, liquid water, and water vapor are assumed to be equal [Brown and Roach, 1976]. The atmospheric stability-dependent exchange coefficients are estimated on the basis of surface roughness, wind speed, and temperature profile [Shir, 1973]. We assume that the thermal conductivity of snow is $0.52 \mathrm{~W} / \mathrm{m} \mathrm{K}$ [Albert and McGilvery, 1992 ] and constant with snow depth.

The condensation rate, $C$, is evaluated at each model time step in the case that a cell is saturated with respect to water vapor. In this case, all of the water vapor above the saturation value is assumed to condense in the liquid phase. The temperature in the cell is then corrected for latent heat effects as described by McDonald [ 1963].

To estimate the gravitational fluxes of fog droplets, it is necessary to know the droplet settling velocity. The relationship between the gravitational flux, $G$, and the fog droplet settling velocity, $u_{a v}$, can be parameterized as

$$
G=w u_{a v}
$$

The fog droplet settling velocity, $u_{a v}$, is parameterized as follows [Brown and Roach, 1976]:

$$
u_{o v}=a_{g} w
$$

A limited number of measurements of fog droplet size distributions were made using an FSSP probe during the 1991 field season at Surnmit and indicate that the mass mean diameter of fog droplets is approximately $20 \mu \mathrm{m}$ [Borys et al., 1992]. Using these data, $a_{g}$ has a mean of $0.20 \mathrm{~m}^{4} / \mathrm{g} \mathrm{s}$. The estimates are made by using equation (6) with the mean liquid water content for the measurements along with estimates of $u_{a v}$ based on Stokes law [Pandis and Seinfeld, 1989a]. The mean $a_{g}$ value at Summit is within the range of values reported by Pandis and Seinfeld [1989a].

\section{Boundary Conditions}

The temperature and water vapor concentration is assumed to be constant at the top of the model domain $(400 \mathrm{~m})$ as well as at $1 \mathrm{~m}$ below the snow surface. The flux of liquid water across the upper boundary is considered to be zero. At the ground surface the temperature of the air and snow are considered to be equal. The condition for the net heat flux at the air/snow interface is used to couple the energy balance in the air and snow and can be written as

$$
-F_{r}+F_{H}+F_{L}-F_{S}=0
$$

where $F_{r}$ is the net longwave and shortwave radiative flux, $F_{H}$ and $F_{S}$ are the sensible heat fluxes through the air and snow, and $F_{L}$ is the latent heat flux. We assume that a quasi-liquid layer exists on the surface of snow crystals [Conklin and Bales, 1993], and the water vapor concentration in the lowest cell is estimated using the method proposed by Turton and Brown [1987], which considers the saturation vapor pressure at the surface as well as the surface resistance to evaporation of water vapor.

The set of partial differential equations are solved using the Crank-Nicholson method with a 1-s time step. For this time step no instabilities occur in the model. A detailed explanation of the fog model is given by Pandis and Seinfeld [1989a].

\section{Gas and Aqueous Phase Chemistry Modules}

The gas phase chemistry mechanism for the $\mathrm{SO}_{2} / \mathrm{NO}_{\mathrm{x}}$ /hydrocarbon system includes 154 reactions with 62 species [Carter and Atkinson, 1988]. The aqueous phase mechanism is from Pandis and Seinfeld [1989b] and contains 49 aqueous phase species, 20 gas-phase aqueous-phase reversible reactions, and 109 aqueous phase reactions. Transport of species between the gas and the aqueous phases is calculated explicitly using the method described by Pandis and Seinfeld [1989b]. The accommodation coefficients $\left(a_{w}\right)$ for gaseous species onto fog droplets is assumed to be 0.01 in the base case simulations [Pandis and Seinfeld, 1989b]. The sensitivity of the model to this parameter will be explored below.

\section{General Model Description}

The computational domain for gas and aqueous phase chemistry is divided into nine cells in the lower $400 \mathrm{~m}$ of the atmosphere, where fog is expected, with three additional cells from $400 \mathrm{~m}$ to $1000 \mathrm{~m}$. Bergin et al. [1994] report that during fog events the dry deposition of aerosols and soluble gases is negligible compared to the flux of these chemical species with fog. Therefore we assume that dry deposition of aerosols and gases during the fog event has a negligible effect on the net fluxes of chemical species (i.e., the dry deposition velocities are assumed to be zero for all of the chemical species). The vertical transport of gases and aerosols is solved using the approach of McRae et al. [1982].

The fog submodel supplies vertical profiles of the liquid water content to the main model. The main model simulates the aqueous phase chemistry, vertical transport of chemical species with fog, and deposition of species with fog to the snow surface. The model assumes that when fog forms in a cell, all of the aerosol mass is scavenged by fog droplets. This 
Table 1. Aerosol and Gas Model Input Concentrations

\begin{tabular}{|c|c|c|c|}
\hline & $\begin{array}{l}\text { Atmospheric } \\
\text { Concentration }\end{array}$ & Source & Comment \\
\hline \multicolumn{4}{|c|}{ Aerosols, $\mathrm{ng} / \mathrm{m}^{3}$} \\
\hline $\mathrm{SO}_{4}{ }^{2-}$ & 340 & Bergin et al. [1995b] & 1993 summer, measurements at Summit \\
\hline $\mathrm{NH}_{4}^{+}$ & 40 & Bergin et al. [1995b] & 1993 summer, measurements at Summit \\
\hline \multicolumn{4}{|c|}{ Gases, ppb } \\
\hline $\mathrm{HNO}_{3}{ }^{*}$ & 0.054 & Dibb et al. [1994] & 1993 summer, measurements at Summit \\
\hline $\mathrm{NO}_{\mathbf{x}}$ & 0.030 & Sandholm et al. [1992] & 1988 summer, Arctic free troposphere \\
\hline $\mathrm{SO}_{2}$ & 0.029 & Dibb et al. [1994] & 1993 summer, measurements at Summit \\
\hline $\mathrm{HCOOH}$ & 1.62 & Dibb et al. [1994] & 1993 summer, measurements at Summit \\
\hline $\mathrm{H}_{2} \mathrm{O}_{2}$ & 1.52 & Bales et al. [1995b] & 1993 summer, measurements at Summit \\
\hline HCHO & 0.50 & Fuhrer, communication, 1995 & 1994 summer, measurements at Summit \\
\hline PAN & 0.54 & Munger, communication, 1995 & 1994 summer, measurements at Summit \\
\hline
\end{tabular}

generally agrees with impactor data in and out of fogs, which suggest that typically all of the coarse mode aerosol mass and at least $70 \%$ of the accumulation mode aerosol mass serve as condensation nuclei during fog formation [Bergin et al., 1995b].

\section{Measured Parameters}

\section{Input Data}

The fog model is applied to a fog event at Summit, Greenland which began on June 21, 1993, at 2000 and lasted until 0600 the following moming. The simulation starts at 1800 on June 21 and ends at 1400 on June 22.

The initial atmospheric temperature profile (at 1800 on June 21) is taken from a tethersonde flight which recorded the temperature, pressure, and wind speed profiles in the lower $500 \mathrm{~m}$ of the atmosphere [Bales et al., 1995b]. Since accurate relative humidity profile measurements are not available, the initial relative humidity is assumed to be constant at $88 \%$ for the $400 \mathrm{~m}$ profile at Summit. The sensitivity of the model to this assumption will be investigated below. The initial temperature profile in the snow is assumed to linearly decrease from the snow surface to a value of $254 \mathrm{~K}$ at $1 \mathrm{~m}$ below the surface. This value is based on snow pit temperature profile measurements made at 1800 on June 21 . The hourly averaged wind speeds used in the model are from a meteorological station at Summit. For most of the fog event the wind speed is approximately $2 \mathrm{~m} / \mathrm{s}$ and increases to $5 \mathrm{~m} / \mathrm{s}$ after 0600 on June 22.

The initial aerosol and gas phase concentrations are given in Table 1. The input concentrations for the aerosol chemical species $\mathrm{SO}_{4}{ }^{2-}$ and $\mathrm{NH}_{4}{ }^{+}$are taken from filter samples collected at the atmospheric camp (ATM) located $10 \mathrm{~km}$ SSW of the GISP2 main camp [Bergin et al., 1995b]. The gas phase concentrations of $\mathrm{HNO}_{3}{ }^{*}, \mathrm{SO}_{2}$, and $\mathrm{HCOOH}$ are from mist chamber samples obtained at the GISP2 main camp reported by Dibb et al. [1994]. It is worthwhile to point out that the nitric acid concentration estimated from $\mathrm{NO}_{3}{ }^{-}$in mist chamber samples is denoted as $\mathrm{HNO}_{3}{ }^{*}$. This is because $\mathrm{NO}_{3}^{-}$ measurements in mist chamber samples may contain contributions from other species such as PAN and organic nitrates $\left(\mathrm{RONO}_{2}\right)$, in addition to $\mathrm{HNO}_{3}[D i b b, 1996]$. This point will be discussed in the section on $\mathrm{HNO}_{3} . \mathrm{H}_{2} \mathrm{O}_{2}$ gas phase concentrations are from measurements conducted at the GISP2 main camp and are reported by Bales et al. [1995a, b]. Although HCHO measurements are not reported for the 1993 field season, values are assumed to be similar to the mean value measured during the 1994 field season at Summit (K. Fuhrer, personal communication 1995). Similarly, direct measurements of PAN have not been made at Summit and the initial PAN concentration is based on $\mathrm{NO}_{\mathrm{y}}$ measurements made during the 1994 field season, which suggest that $\mathrm{HNO}_{3}$ is typically less than $10 \%$ of the total atmospheric $\mathrm{NO}_{\mathrm{y}}$ (J.W. Munger, personal communication 1995). The $\mathrm{NO}_{\mathrm{y}}$ values measured during the 1994 field season ranged from $0.3 \mathrm{ppb}$ to $5 \mathrm{ppb}$. We therefore assume that a large fraction of the $\mathrm{NO}_{\mathrm{y}}$ at Summit is PAN and approximate the initial PAN concentration as 10 times the initial $\mathrm{HNO}_{3}{ }^{*}$ concentration. Since $\mathrm{NO}_{\mathrm{x}}$ measurements have not been made at Summit, the concentrations of $\mathrm{NO}$ and $\mathrm{NO}_{2}$ are assumed to be $10 \mathrm{ppt}$ and $20 \mathrm{ppt}$, respectively. These values are based on measurements made in the Arctic free troposphere during the ABLE $3 \mathrm{~A}$ missions [Sandholm, 1992]. The concentrations of $\mathrm{CH}_{4}$ and $\mathrm{CO}$ are assumed to be their global background values of 1.7 ppm and 75 ppb, respectively [Thompson et al., 1993].

Both aerosol and gas phase measurements were made at ground level $(1.5 \mathrm{~m})$. Since vertical profiles of aerosols and gases have not been measured, we assume that the initial 


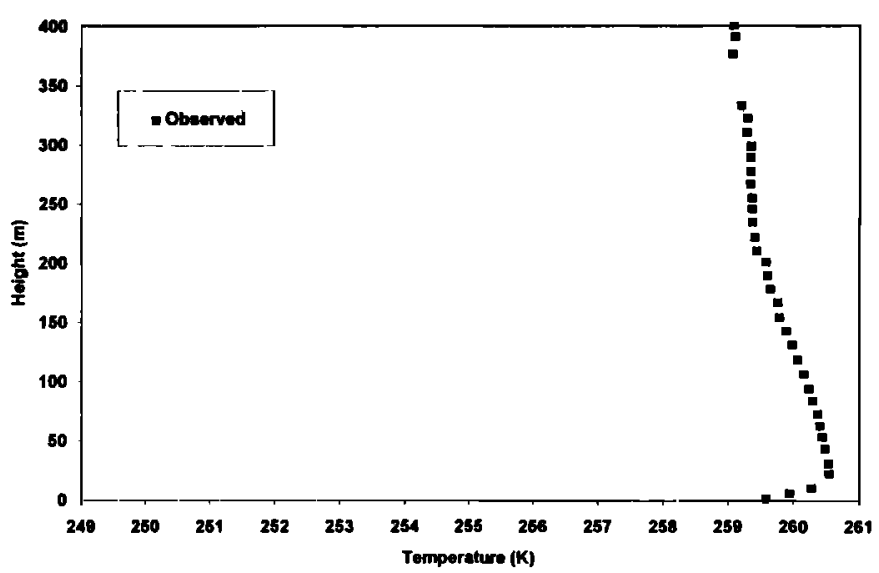

(a)

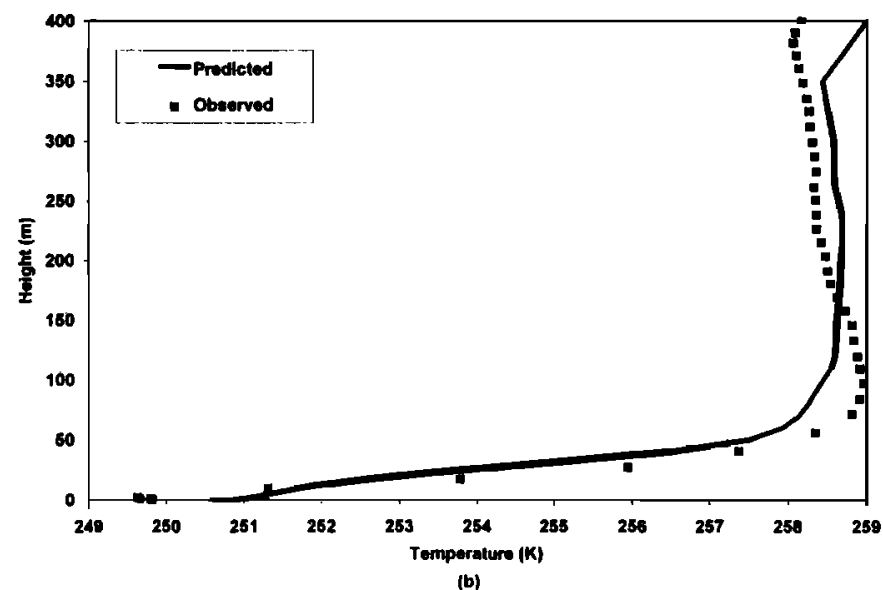

Figure 1. (a) Measured initial atmospheric temperature profile on June 21 at 1815 (used as model initial condition) and (b) observed versus predicted temperature profile on June 22 at 0000 .

concentration profiles are uniform with the same values as the concentrations measured at ground level.

\section{Fog Chemical Fluxes}

Fluxes of several chemical species for the fog event occurring at 1800 on June 21 and ending at 0600 on June 22 were measured by Bergin et al. [1995b]. Fog samples were analyzed for $\mathrm{SO}_{4}{ }^{2-}$ and $\mathrm{NO}_{3}{ }^{-}$by ion chromatography (IC) [Bergin et al., 1995b] and for $\mathrm{H}_{2} \mathrm{O}_{2}$ [Bales et al., 1995]. The fluxes of the chemical species are estimated by multiplying the concentrations by the mass of fog deposited per area. The fluxes of the chemical species estimated between replicate samples are within $10 \%$.

\section{Model Results and Discussion}

\section{Fog Development}

The model predicts that the fog begins at 2000 and dissipates the following morning at 0600 , in agreement with field observations. Figure la shows the atmospheric temperature profile on June 21 at 1815 , which serves as an initial condition for the atmospheric energy balance (equation (1)). The observed and predicted temperature profiles on June
22 at 0000 , several hours into the fog event, are depicted in Figure lb. It is worthwhile to point out that the model accurately reproduces the $10^{\circ} \mathrm{K}$ cooling observed at the ground level as well as the cooling in the bottom $100 \mathrm{~m}$ of the atmosphere. This suggests that the model correctly estimates the eddy diffusivity, which is a function of several parameters including the atmospheric stability, wind speed, and surface roughness. This parameter is crucial in correctly estimating the fluxes of heat as well as gas phase species. Also, the heat flux boundary condition (equation (7)) that couples the air and snow compartments appears adequate.

Figure $2 \mathrm{a}$ shows the predicted liquid water content (LWC) in the lowest model cell during the fog event. The mean LWC in the bottom cell for the fog event is $0.075 \mathrm{~g} / \mathrm{m}^{3}$. Although measurements of the LWC were not made during the 1993 field season, $\mathrm{LWC}$ measurements in similar fog events during the 1991 field season ranged from $0.03 \mathrm{~g} / \mathrm{m}^{3}$ to $0.30 \mathrm{~g} / \mathrm{m}^{3}$ [Borys et al., 1992], in general agreement with the LWC predicted in Figure 2a. The cumulative flux of fog water to the surface is shown in Figure 2b. From 2300 on June 21 to 0200 on June 22 the cumulative flux curve is linear, which suggests the fog droplet flux to the surface is constant during this time period. This is due to the relatively constant LWC in the lowest cell during this time period, which determines the water flux. For the last 3 hours of the fog event the cumulative flux levels off, which is due to the significant decrease in the LWC as the fog dissipates. The predicted evolution of the LWC vertical profile during the fog event is given in Figure 2c. The fog builds to a height of $140 \mathrm{~m}$ on June 22 at 0400 , at which time the mean vertical liquid water content is 0.07 $\mathrm{g} / \mathrm{m}^{3}$. The atmospheric temperature begins to increase due to radiative heating of the ground and the conduction of heat from deeper snow to the snow surface and the fog completely dissipates on June 22 at 0600.

\section{Gas Phase Concentrations During Fog}

Hydrogen peroxide $\left(\mathrm{H}_{2} \mathrm{O}_{2}\right)$. Figure 3 a shows predicted and observed gas phase concentrations of $\mathrm{H}_{2} \mathrm{O}_{2}$ in the ground cell during fog. $\mathrm{H}_{2} \mathrm{O}_{2}$ can react with $\mathrm{SO}_{2}$ dissolved in cloud and fog water to produce $\mathrm{SO}_{4}{ }^{2-}$ [Daum et al., 1983; Pandis and Seinfeld; 1989b] and therefore enhances the deposition of S(VI) with fog. The model results generally agree with measured values, although the model appears to underestimate the $\mathrm{H}_{2} \mathrm{O}_{2}$ concentration during the fog event. The model results suggest that all of the $\mathrm{H}_{2} \mathrm{O}_{2}$ enters the aqueous phase, while the measurements show that approximately $20 \%$ of the initially present $\mathrm{H}_{2} \mathrm{O}_{2}$ remains in the gas phase. If the measured gas phase value of $0.4 \mathrm{ppb}$ during the fog event is considered an equilibrium value, then Henry's law predicts that the fog water eoncentration should be 720 $\mu \mathrm{M}$. The measured fog water $\mathrm{H}_{2} \mathrm{O}_{2}$ concentration is only 50 $\mu \mathrm{M}$, more than an order of magnitude lower than the equilibrium esumation. This suggests that either the measurement technique is biased or that equilibrium is not reached in the timescale of the fog. Measurements by Noone et al. [1991] have suggested that $\mathrm{H}_{2} \mathrm{O}_{2}$ is apparently close to Henry's law equilibrium in ambient clouds. The estimated timescale for equilibrium should be of the order of several 
minutes, and therefore the latter explanation is not satisfactory. The difference in measured and predicted gas phase concentrations may be due to the sampling of fog droplets by the instrument, which would result in an overestimation of the atmospheric $\mathrm{H}_{2} \mathrm{O}_{2}$ concentration (M. Losleben, personal communication 1995) although this cannot
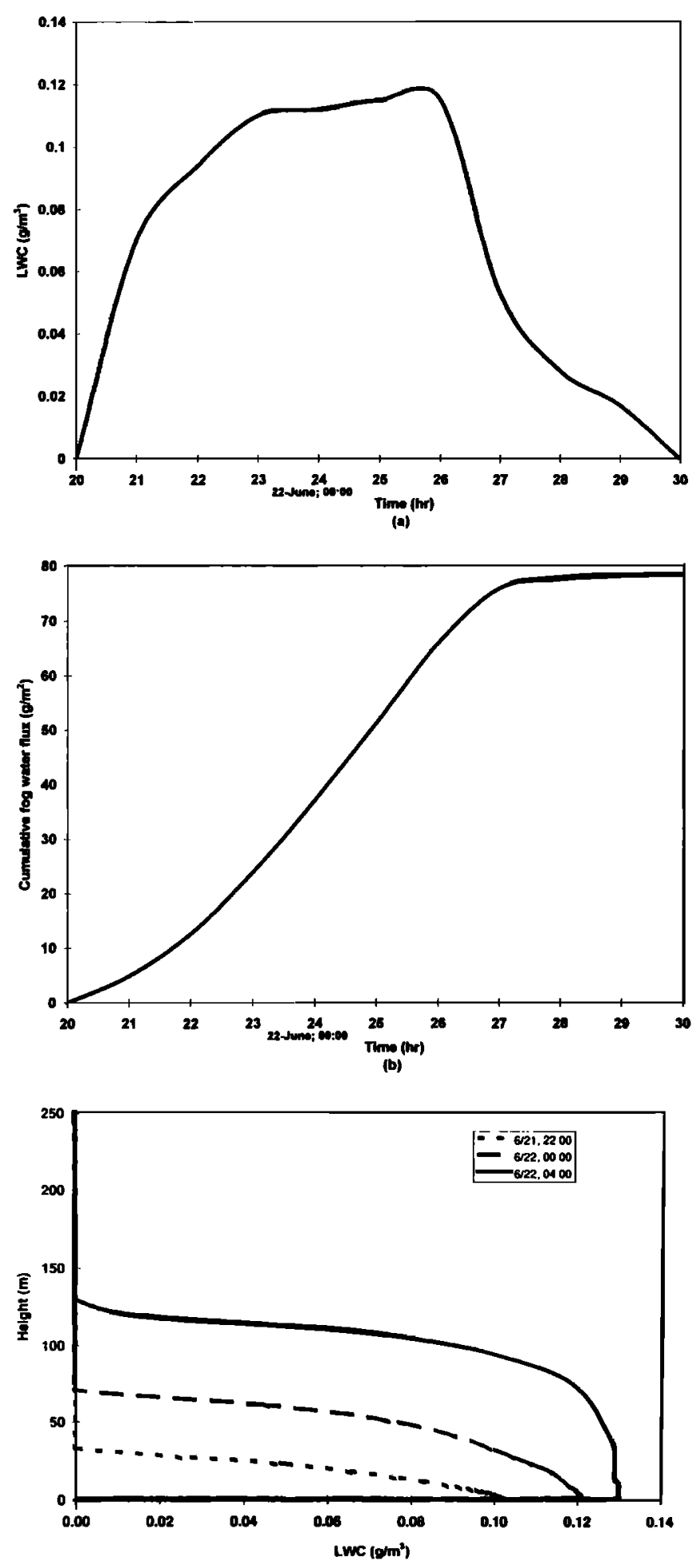

Figure 2. (a) Liquid water content (LWC) in the lowest cell during fog (b) cumulative water flux during the fog event, and (c) LWC profile for 3 times during the fog event. be quantitatively verified. It is not likely that entrainment from higher concentration air above the fog region affects surface concentrations during the fog event, since the atmosphere in the fog region is extremely stable. Gill et al. [1983] suggest that organic compounds may coat the surface of droplets, affecting the mass transport of gases between the gas and the aqueous phases. Winiwater et al. [1994] also suggest that the presence of organic surface coatings may affect mass transport to droplets. Unfortunately, there is not a great deal of information available on the effect of droplet surface coatings on mass transport, and experiments performed at Summit do not allow the existence of such surface coatings to be substantiated. The effect of a surface coating can be parameterized by decreasing the droplet accommodation coefficient and will be discussed below. $\mathrm{H}_{2} \mathrm{O}_{2}$ is relatively soluble in fog water and Figure 3a shows that the gas phase $\mathrm{H}_{2} \mathrm{O}_{2}$ concentration significantly decreases within the first few hours of fog. During the fog event, $\mathrm{H}_{2} \mathrm{O}_{2}$ is lost due to scavenging by fog droplets and deposition to the ground. After the fog event the $\mathrm{H}_{2} \mathrm{O}_{2}$ concentration gradually increases due to mixing with higher concentration air from aloft, which was above the fog layer during the fog event.

Formic acid (HCOOH). Figure $3 \mathrm{~b}$ shows the predicted and observed gas phase concentrations of formic acid $(\mathrm{HCOOH})$. Both the model results and the measurements are in general agreement and show that $\mathrm{HCOOH}$ concentrations decrease during the fog event. However, a significant fraction of $\mathrm{HCOOH}$ remains in the gas phase, which is expected for this moderately soluble species [Pandis and Seinfeld, 1989b; Dibb et al.,1994]. At about 0400 the fog begins to dissipate and the concentration gradually increases due to mixing with air alof, until about 0700 . After this time the concentration of HCOOH gradually decreases until the end of the simulation. This is due to the gas phase destruction of $\mathrm{HCOOH}$ by reaction with $\mathrm{OH}$ [Carter and Atkinson, 1988].

Sulfur dioxide $\left(\mathrm{SO}_{2}\right)$. Figure $3 \mathrm{c}$ shows predicted and observed $\mathrm{SO}_{2}$ concentrations during fog. The model predicts that essentially all of the $\mathrm{SO}_{2}$ is transferred from the gas phase to the aqueous phase within the first several hours of the fog. In the aqueous phase $\mathrm{S}(\mathrm{IV})$ reacts with $\mathrm{H}_{2} \mathrm{O}_{2}$ to produce S(VI), which will be discussed in more detail below. Although the uncertainties in the gas phase $\mathrm{SO}_{2}$ measurements are quite high, the model results apparently underpredict the $\mathrm{SO}_{2}$ concentrations during fog. Because of the low wind speeds and stable atmospheric conditions during fog, it is not likely that significant transport of $\mathrm{SO}_{2}$ from above the fog model spatial domain ( $400 \mathrm{~m}$ ) occurred. It is also not likely that local contamination from the GISP2 camp contributed to $\mathrm{SO}_{2}$ concentrations, since the camp was $1 \mathrm{~km}$ downwind of the sample sight for the duration of the measurements. It is likely that the mist chamber measurements are very close to the detection limit and the discrepancy between the model results and the measurements may be due to the accuracy of the mist chamber technique under the particular sampling conditions at Summit.

Nitric acid ( $\left.\mathrm{HNO}_{3}\right) . \mathrm{NO}_{3}{ }^{-}$is the dominant ionic species in ice core samples and includes contributions from 

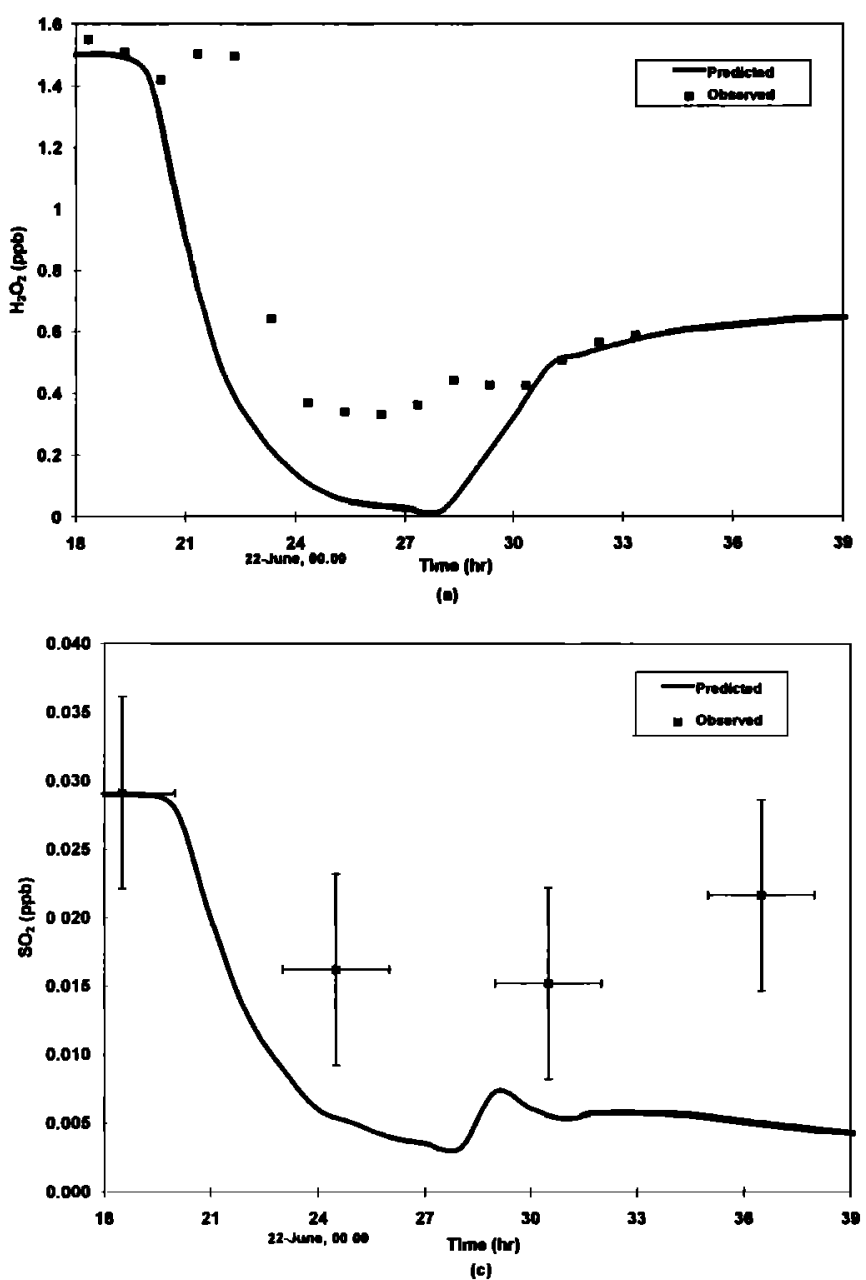

Figure 3. Predicted and observed atmospheric gas phase concentrations of (a) $\mathrm{H}_{2} \mathrm{O}_{2}$, (b) formic acid (HCOOH), (c) $\mathrm{SO}_{2}$

anthropogenic and natural sources [Silvente and Legrand, 1995]. As previously discussed, $\mathrm{NO}_{3}^{-}$collected in mist chamber samples may originate from $\mathrm{HNO}_{3}$ vapor as well as from other $\mathrm{NO}_{\mathrm{y}}$ species such as $\mathrm{PAN}, \mathrm{RONO}_{2}$, or other organic nitrates [Sandholm et al., 1992] here written as $\mathrm{NO}_{\mathbf{y}}{ }^{*}$. Measurements of PAN and $\mathrm{RONO}_{2}$ species reported for early spring at Alert suggest that PAN concentrations are typically 10 times greater than $\mathrm{RONO}_{2}$ concentrations [Muthuramu et al., 1995]. Measurements carried out during the Arctic Boundary Layer Expedition (ABLE 3A) also indicate that $\mathrm{RONO}_{2}$ concentrations are less than $10 \%$ of PAN concentrations [Singh et al., 1992]. It is likely that the majority of the $\mathrm{NO}_{\mathrm{y}}$ at Summit is PAN, although the existence of other organic nitrates cannot be ruled out. Therefore $\mathrm{HNO}_{3}$ values estimated from $\mathrm{NO}_{3}^{-}$in mist chamber samples $\left(\mathrm{HNO}_{3}{ }^{*}\right)$ are likely overestimates of the actual gas phase $\mathrm{HNO}_{3}$ concentrations, and the $\mathrm{HNO}_{3}{ }^{*}$ concentration can be written as

$$
\mathrm{HNO}_{3} *=\mathrm{HNO}_{3}+\mathrm{NO}_{4} *
$$

Figure 3d shows $\mathrm{HNO}_{3}{ }^{*}$ concentrations for two model runs along with measured values. Two hypotheses are tested with
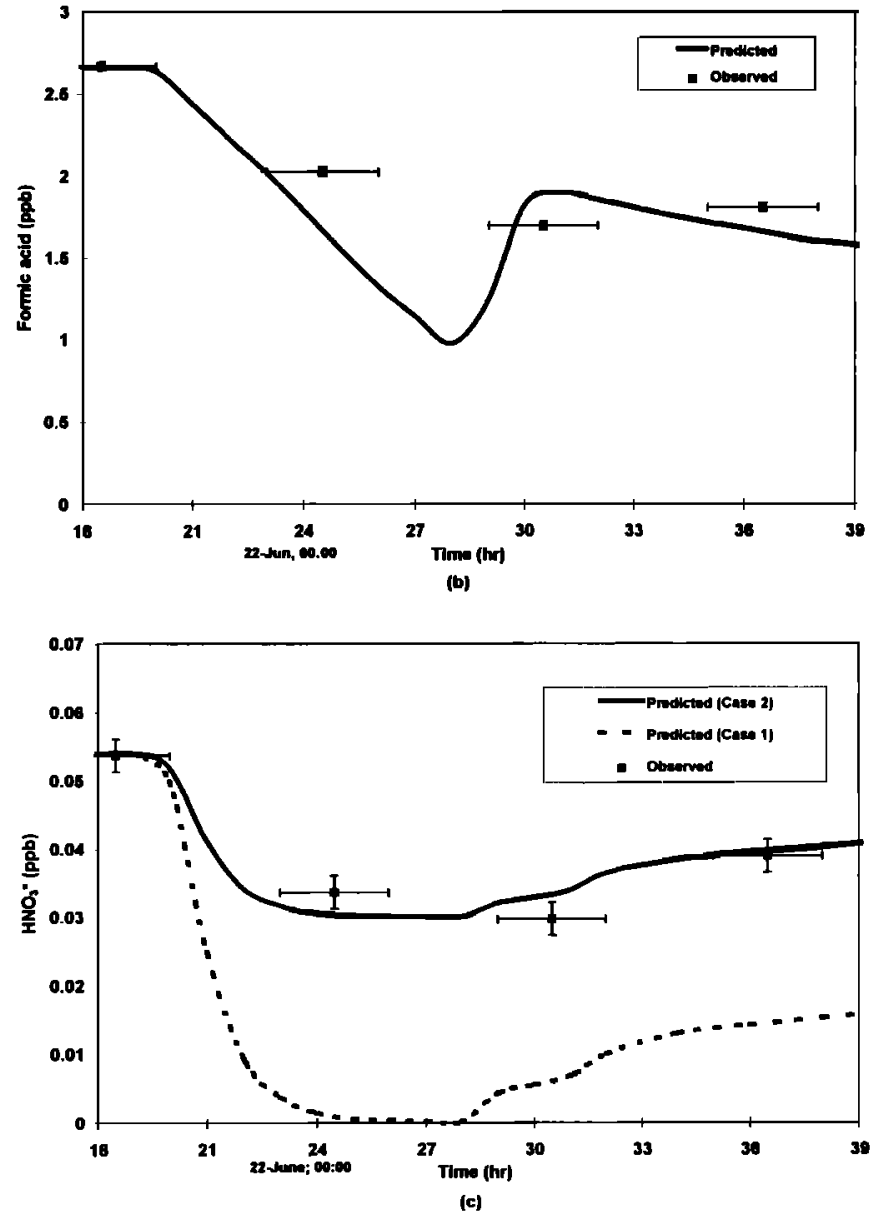

and (d) $\mathrm{HNO}_{3}^{*}$ (case $\mathrm{l}$ is $\mathrm{HNO}_{3}, \mathrm{i}=0.054 \mathrm{ppb}, \mathrm{NO}^{*}=0.000$ $\mathrm{ppb}$; case 2 is $\mathrm{HNO}_{3}, \mathrm{i}=0.024 \mathrm{ppb}, \mathrm{NO}^{*}=0.030 \mathrm{ppb}$ ).

the model: (1) All of the $\mathrm{NO}_{3}^{-}$in mist chamber samples is from $\mathrm{HNO}_{3}$ (i.e. $\mathrm{HNO}_{3}$, initial $=0.054 \mathrm{ppb} ; \mathrm{NO}^{*}=0.000$ ). (2) The total decrease in the measured $\mathrm{HNO}_{3}{ }^{*}$ concentration during the fog is the actual initial $\mathrm{HNO}_{3}$ atmospheric concentration, and some other $\mathrm{NO}^{*}$ species contributes to mist chamber $\mathrm{NO}_{3}^{-}$in addition to $\mathrm{HNO}_{3}$ (i.e. $\mathrm{HNO}_{3}$, initial $=0.024 \mathrm{ppb}, \mathrm{NO}^{*}=0.030 \mathrm{ppb}$ ). Figure $3 \mathrm{~d}$ shows model results for cases 1 and 2 . The modeled $\mathrm{HNO}_{3}{ }^{*}$ concentrations are determined using equation (8). For case 1 the model predicts that essentially all of the $\mathrm{HNO}_{3}{ }^{*}$ initially present in the gas phase, in the lowest cell, is transferred to fog droplets within the first several hours of the fog. This is not surprising since $\mathrm{HNO}_{3}$ is extremely soluble in fog water [Pandis and Seinfeld, 1989a]. However, measurements suggest that only about $40 \%$ of the $\mathrm{HNO}_{3}{ }^{*}$ enters the aqueous phase.

It is possible that the discrepancy between predicted and observed $\mathrm{HNO}_{3}{ }^{*}$ concentrations may be due to mist chamber sampling artifacts during fog. During sampling, fog droplets collect on the Teflon prefilter of the mist chamber. It is possible that $\mathrm{HNO}_{3}$ degases from these fog droplets and is collected in the mist chamber (J.E. Dibb, personal communication 1995). This would result in an overestimation 
Table 2. Observed and Modeled Fog Fluxes

\begin{tabular}{lcc}
\hline & $\begin{array}{c}\text { Observed Flux, } \\
\mathrm{ug} / \mathrm{m}^{2}\end{array}$ & $\begin{array}{c}\text { Modeled Flux, } \\
\mathrm{ug} / \mathrm{m}^{2}\end{array}$ \\
\hline S(VI) & 40 & 41 \\
$\mathrm{~N}(\mathrm{~V})$ & 12 & 14 \\
$\mathrm{H}_{2} \mathrm{O}_{2}$ & 400 & 310 \\
Fog water, $\mathrm{g} / \mathrm{m}^{2}$ & 122 & 80 \\
\hline
\end{tabular}

of the measured gas phase $\mathrm{HNO}_{3}^{*}$ concentration, since some of the $\mathrm{HNO}_{3}$ sampled is from fog droplets. It is worthwhile to note that the model appears to underpredict the atmospheric concentrations for all of the gas phase species studied, although the discrepancy is most apparent for $\mathrm{HNO}_{3}$. It is more likely that some other species $\left(\mathrm{NO}^{*}\right)$ contributes to $\mathrm{NO}_{3}{ }^{-}$in the mist chamber during sampling, or during storage of the samples before analysis. Indeed, $\mathrm{NO}_{\mathrm{y}}$ measurements made during the 1994 field season suggest that $\mathrm{HNO}_{3}$ is only a small fraction of the total $\mathrm{NO}_{\mathrm{y}}$ (J.W. Munger, personal communication 1995). If we assume for case 1 that the $\mathrm{HNO}_{3}^{*}$ measurements represent the actual $\mathrm{HNO}_{3}$ concentrations and that after the first several hours the gas and aqueous phases are in equilibrium, Henry's law estimates that the aqueous phase $N(V)$ concentration should be approximately $500 \mu \mathrm{M}$. The measured $\mathrm{N}(\mathrm{V})$ concentration in deposited fog droplets is $1.0 \mu \mathrm{M}$, which is more than 2 orders of magnitude less than what is expected if $\mathrm{HNO}_{3}$ is in equilibrium between the gas and the aqueous phase. This is indirect evidence that the mist chamber measures $\mathrm{NO}_{3}{ }^{-}$from another species, in addition to $\mathrm{HNO}_{3}$.

The mist chamber measurements show that the $\mathrm{HNO}_{3}{ }^{*}$ concentration decreases by $0.024 \mathrm{ppb}$ during the fog event. Case 2 in Figure 3d assumes that the initial $\mathrm{HNO}_{3}$ concentration is $0.024 \mathrm{ppb}$ and that the contribution of $\mathrm{NO}^{*}$ to mist chamber $\mathrm{NO}_{3}^{-}$has a constant value of $0.03 \mathrm{ppb}$. In this case, the predicted and observed $\mathrm{HNO}_{3}{ }^{*}$ concentrations are in agreement. Therefore model results suggest that the decrease in the $\mathrm{HNO}_{3}$ * concentration is due to $\mathrm{HNO}_{3}$ incorporation in fog droplets and that there is likely another chemical species $\left(\mathrm{NO}_{\mathrm{y}}{ }^{*}\right)$ that contributes to $\mathrm{NO}_{3}{ }^{-}$in mist chamber samples.

\section{Fluxes of Chemical Species With Fog Droplets}

Table 2 shows the predicted and observed fluxes of various chemical species with fog for initial base case concentrations (the base case assumes Table 1 values with an initial $\mathrm{HNO}_{3}$ concentration of $0.024 \mathrm{ppb}$ ). The predicted fluxes of chemical species and fog water generally agree with measurements. The predicted water droplet flux is approximately $30 \%$ lower than the measured flux. It is possible that the model underestimates the LWC during fog, which is the critical parameter used to estimate the fog droplet flux. The underprediction of the fog droplet flux may result in lower chemical species fluxes than measured values. This may be the case for $\mathrm{H}_{2} \mathrm{O}_{2}$, although the chemical species fluxes depend on several factors, the most important being the initial gas and aerosol concentrations. The

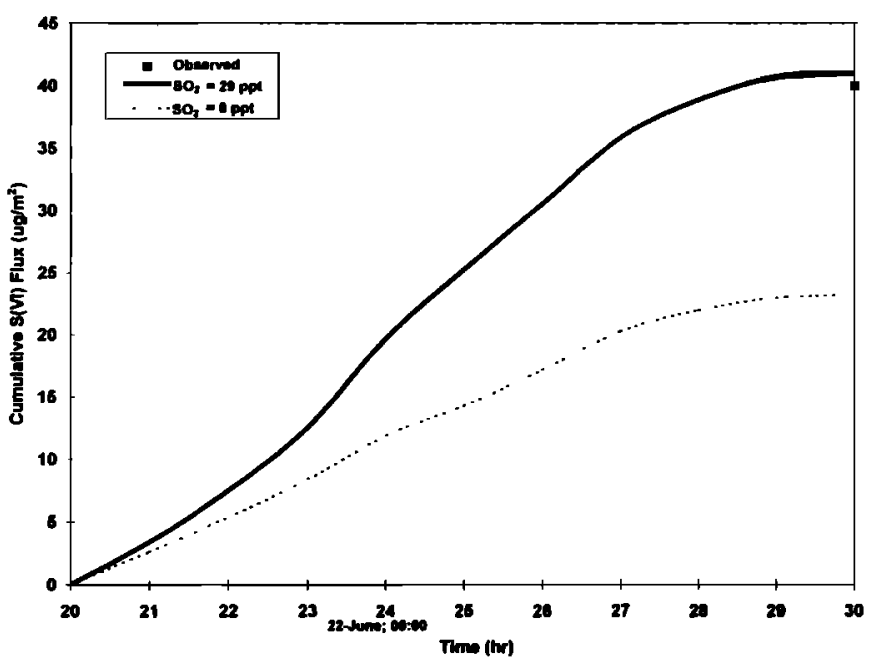

Figure 4. Predicted cumulative $\mathrm{S}(\mathrm{VI})$ fluxes for $\mathrm{SO}_{2}$ values of $29 \mathrm{ppt}$ and $0 \mathrm{ppt}$.

$\mathrm{N}(\mathrm{V})$ flux is most likely overestimated by the model due to one or more of the unknown initial concentrations (PAN, $\mathrm{NO}_{\mathbf{x}}$ ) being higher than the actual concentration. The sensitivity of the fluxes of water and chemical species with fog to the model initial conditions is discussed below.

\section{Sulfate Production in Fog}

Figure 4 shows the impact of the initial $\mathrm{SO}_{2}$ concentration on the predicted deposition of $\mathrm{S}(\mathrm{VI})$ due to the aqueous phase oxidation of $\mathrm{S}(\mathrm{IV})$ by $\mathrm{H}_{2} \mathrm{O}_{2}$. The cumulative deposition curves for S(VI) with initial $\mathrm{SO}_{2}$ concentrations of $29 \mathrm{ppt}$ and $0 \mathrm{ppt}$ are shown in Figure 4. In the absence of $\mathrm{SO}_{2}$ the deposition of $\mathrm{S}(\mathrm{VI})$ is due to the nucleation scavenging of sulfate aerosols by fog droplets. The model predicts that the deposition of S(VI) due to nucleation scavenging of sulfate aerosol is 23 $\mu \mathrm{g} / \mathrm{m}^{2}$. This is significantly lower than the measured value of $40 \mu \mathrm{g} / \mathrm{m}^{2}$ given in Table 2. Using the measured initial $\mathrm{SO}_{2}$ concentration of $29 \mathrm{ppt}$, the model predicts that the S(VI) flux is $41 \mu \mathrm{g} / \mathrm{m}^{2}$, which agrees with the measured value. This increased depositional flux is due to the conversion of S(IV) to $\mathrm{S}(\mathrm{VI})$ by aqueous phase reaction with $\mathrm{H}_{2} \mathrm{O}_{2}$. The model results suggest that the aqueous phase production of $\mathrm{S}(\mathrm{VI})$ accounts for roughly $40 \%$ of the total S(VI) deposition, with nucleation scavenging of sulfate aerosols contributing $60 \%$. Unfortunately, uncertainties in the $\mathrm{SO}_{2}$ measurements make quantitative estimates of the S(VI) deposition due to aqueous phase production uncertain. This model result shows that the deposition of $\mathrm{S}(\mathrm{VI})$ with fog at Summit is sensitive to $\mathrm{SO}_{2}$ concentrations and that accurate measurements of $\mathrm{SO}_{2}$ are needed to determine the extent to which aqueous phase production of S(VI) may affect deposition.

The initial molar ratio of $\mathrm{SO}_{2}$ to aerosol $\mathrm{SO}_{4}{ }^{2-}$ for the fog of June 21 is 0.4 . The model predicts that both of these species are completely scavenged from the atmosphere by fog, and therefore the $\mathrm{SO}_{2}$ contributes roughly $40 \%$ of the $\mathrm{S}(\mathrm{VI})$ fog flux. Aerosol and gas phase measurements made during the 1993 field season at Summit suggest that the atmospheric $\mathrm{SO}_{2} / \mathrm{SO}_{4}{ }^{2-}$ ratio is typically less than 0.30 [Dibb et al., 1994]. 
Therefore it is possible that a more representative sulfate deposition enhancement due to $\mathrm{SO}_{2}$ is $30 \%$ or less.

\section{N(V) Deposition}

There are several nitrogen containing species at Summit that may be responsible directly or indirectly for varying fractions of the deposition of $\mathrm{N}(\mathrm{V})$ with fog. These chemical species include $\mathrm{NO}_{x}, \mathrm{HNO}_{3}$, and PAN. Figure 5 shows the predicted effect of the assumed initial atmospheric concentrations of $\mathrm{NO}_{\mathrm{x}}, \mathrm{HNO}_{3}$, and PAN on the deposition of $N(V)$ with fog. For case 1 in Figure 5 the base case initial atmospheric concentrations are assumed with $\mathrm{HNO}_{3}$ and PAN equal to zero. In this case, the $\mathrm{N}(\mathrm{V})$ fog flux is due primarily to the gas phase conversion of $\mathrm{NO}_{2}$ to $\mathrm{HNO}_{3}$ [Carter and Atkinson, 1988]:

$$
\mathrm{OH}(\mathrm{g})+\mathrm{NO}_{2}(\mathrm{~g}) \longrightarrow \mathrm{HNO}_{3}(\mathrm{~g})
$$

During the fog event, fog droplets absorb UV solar radiation (we assume a photolytic reduction of $50 \%$ within the fog layer) and reduce the photolytic production of $\mathrm{OH}$. A second path of $\mathrm{HNO}_{3}$ production exists as follows [Russell et al., 1986]: $\mathrm{NO}_{2}$ reacts with $\mathrm{O}_{3}$ to create the nitrate radical

$$
\mathrm{NO}_{2}(\mathrm{~g})+\mathrm{O}_{3}(\mathrm{~g}) \longrightarrow \mathrm{NO}_{3}(\mathrm{~g})+\mathrm{O}_{2}(\mathrm{~g})
$$

During the day, $\mathrm{NO}_{3}$ is photochemically destroyed, but inside the fog layer the destruction is slowed due to the decrease in UV radiation. The following reaction then occurs:

$$
\mathrm{NO}_{3}(\mathrm{~g})+\mathrm{NO}_{2}(\mathrm{~g}) \longrightarrow \mathrm{N}_{2} \mathrm{O}_{5}(\mathrm{~g})
$$

$\mathrm{N}_{2} \mathrm{O}_{5}$ will then react with water vapor as follows [Carter and Atkinson, 1988]:

$$
\mathrm{N}_{2} \mathrm{O}_{5}(\mathrm{~g})+\mathrm{H}_{2} \mathrm{O}(\mathrm{g}) \longrightarrow 2 \mathrm{HNO}_{3}(\mathrm{~g})
$$

This equation neglects the possible heterogeneous reaction of $\mathrm{N}_{2} \mathrm{O}_{5}$ with water droplets. For the atmospheric conditions at Summit the rate of production of $\mathrm{N}_{2} \mathrm{O}_{5}$ during fog from (R3) is typically $1 / 3$ the rate of destruction from (R4). Therefore increasing the rate constant of (R4) to consider heterogeneous chemistry on the surface of fog droplets in this case does not influence the production of $N(V)$, since (R3) is the rate limiting step. For case 1 the total $N(V)$ deposition with fog droplets is $4.6 \mu \mathrm{g} / \mathrm{m}^{2}$. The $\mathrm{NO}_{2}+\mathrm{OH}$ reaction accounts for $65 \%$ of the $\mathrm{HNO}_{3}$ formation, with the $\mathrm{N}_{2} \mathrm{O}_{5}+\mathrm{H}_{2} \mathrm{O}$ accounting for the other $35 \%$. (R1) is sensitive to the $\mathrm{OH}$ concentration and the model predicts that the $\mathrm{OH}$ concentrations range from $0.3 \times 10^{5}$ molecules $/ \mathrm{cm}^{3}$ in the middle of the fog event to $0.6 \mathrm{x}$ $10^{6}$ molecules $/ \mathrm{cm}^{3}$ at 0600 on June 22 immediately after the fog event. These values generally agree with the values expected for the Arctic free troposphere during the middle of the summer [Jacob et al., 1992].

For case 2 in Figure 5, base case atmospheric

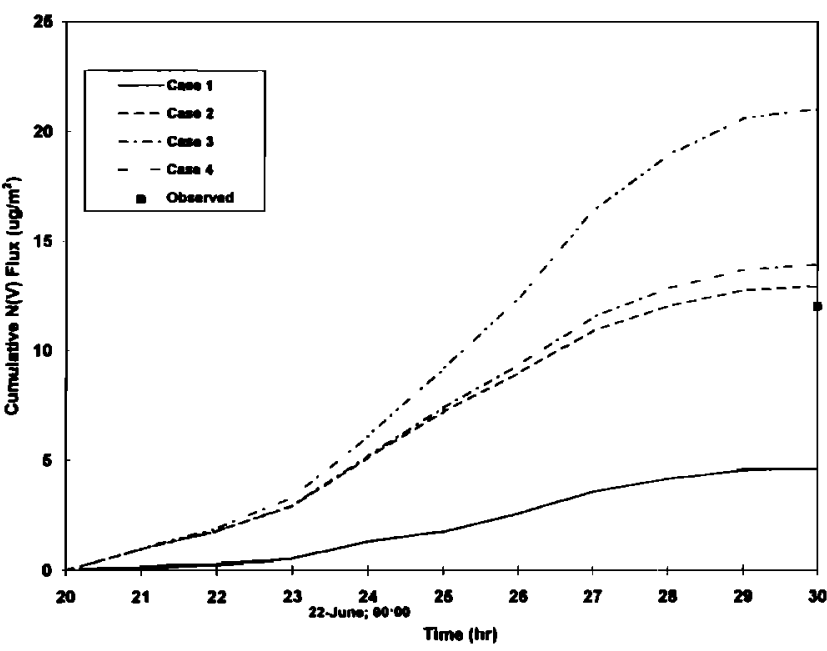

Figure 5. Predicted cumulative $N(V)$ fluxes for case 1 (base case with $\mathrm{HNO}_{3}$ and PAN equal to zero), case 2 (base case with $\mathrm{HNO}_{3}$ and $\mathrm{PAN}$ equal to 0.024 and $0.000 \mathrm{ppb}$, respectively), case 3 (base case with $\mathrm{HNO}_{3}$ and PAN equal to 0.024 and $0.540 \mathrm{ppb}$, respectively), and case 4 (base case with $\mathrm{HNO}_{3}$ and PAN equal to 0.024 and $5.000 \mathrm{ppb}$, respectively).

concentrations are assumed with initial $\mathrm{HNO}_{3}$ and $\mathrm{PAN}$ concentrations of $0.024 \mathrm{ppb}$ and $0 \mathrm{ppb}$, respectively. In this case the aqueous phase $\mathrm{N}(\mathrm{V})$ originates from the initial $\mathrm{HNO}_{3}$ concentration as well as from (Rl) and (R4). The total N(V) flux is $12.9 \mu \mathrm{g} / \mathrm{m}^{2}$, which suggests that approximately $65 \%$ of the $\mathrm{N}(\mathrm{V})$ flux is due to the incorporation of the initial $\mathrm{HNO}_{3}$ in fog droplets.

Case 3 assumes base case atmospheric concentrations with $\mathrm{HNO}_{3}$ and PAN concentrations of $0.024 \mathrm{ppb}$ and $0.54 \mathrm{ppb}$, respectively. In this case additional $N(V)$ is deposited to surface snow due to the decomposition of PAN in both the gas and the aqueous phases. The gas phase decomposition of PAN is as follows [Atkinson and Lloyd, 1984]:

$$
\mathrm{PAN}(\mathrm{g}) \longrightarrow \mathrm{RCO}_{3}(\mathrm{~g})+\mathrm{NO}_{2}(\mathrm{~g})
$$

$\mathrm{NO}_{2}$ then forms $\mathrm{HNO}_{3}$ through (R1) and (R4). $\mathrm{N}(\mathrm{V})$ may also be produced due to the partitioning of PAN between the gas and the aqueous phase and the following reaction [Lee, 1984]:

$$
\mathrm{PAN}(\mathrm{aq}) \longrightarrow \mathrm{NO}_{3}-(\mathrm{aq})+\operatorname{Products}(\mathrm{aq})
$$

Figure 5 shows that for case 3, PAN decomposition contributes about $10 \%$ to the flux of $N(V)$ with fog. The gas and aqueous phase production of N(V) in the lower $200 \mathrm{~m}$ of the atmosphere for case 3 atmospheric concentrations is shown in Figure 6. (RI) accounts for $65 \%$ of the N(V) formation, with $30 \%$ being contributed from (R4), and $5 \%$ from (R5). It is worthwhile to note that (R6) accounts for about $20 \%$ of the N(V) production from PAN, with (R5) accounting for the majority of the production through the formation of $\mathrm{NO}_{2}$ and subsequent reactions to make $\mathrm{HNO}_{3}$. 


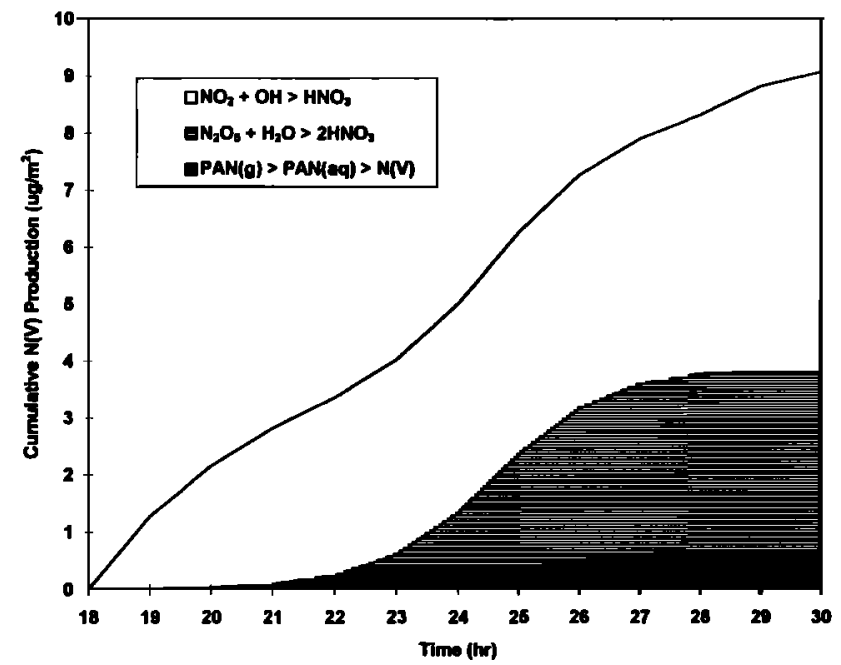

Figure 6. Contributions of reactions (1), (4), and (6) to the cumulative $\mathrm{N}(\mathrm{V})$ flux.

As mentioned earlier, $\mathrm{NO}_{\mathrm{y}}$ values measured during the 1994 summer field season ranged from $0.3 \mathrm{ppb}$ to $5.0 \mathrm{ppb}$. Case 4 assumes base case concentrations, with an initial PAN concentration equal to the upper limit $\mathrm{NO}_{\mathrm{y}}$ value of $5.0 \mathrm{ppb}$. For this case the results show that PAN can have a significant effect on the deposition of N(V) and accounts for about $40 \%$ of the total N(V) deposition with fog.

Unfortumately, there are neither direct PAN nor $\mathrm{NO}_{\mathrm{y}}$ measurements available for the 1993 field season. Indeed, PAN concentration measurements have not been made at Summit and the range of PAN values is based on $\mathrm{NO}_{\mathrm{y}}$ measurements made during the 1994 field season. Values of PAN reported during summer in the Arctic free troposphere from ABLE 3A [Singh et al., 1992] and ABLE 3B [Fan et al., 1994] are typically from $0.1 \mathrm{ppb}$ to $0.5 \mathrm{ppb}$. Therefore it is likely that the actual PAN concentration at Summit is closer to $0.54 \mathrm{ppb}$ than to $5.0 \mathrm{ppb}$. Figure 5 is merely meant to show the importance of the relative contributions of nitrogencontaining species $\mathrm{HNO}_{3}, \mathrm{NO}_{2}$, and PAN to the deposition of N(V).

\section{Sensitivity of Estimated Fog Fluxes to Model Parameters}

Several model parameters are relatively uncertain and the sensitivity of our conclusions to their selected base case values is investigated in this section. In particular, the sensitivity of the modeled fog water and chemical species fluxes to the fog droplet settling velocity parameterization as well as the initial relative humidity profile and accommodation coefficient will be explored.

\section{Settling Velocity Parameterization}

In the base case simulations we assume that the fog droplet settling velocity parameter, $a_{g}$, is $0.20 \mathrm{~m}^{4} / \mathrm{g} \mathrm{s}$. This is based on FSSP measurements made by Borys et al. [1992]. The $a_{g}$ values estimated from the measurements range from about 0.1 $\mathrm{m}^{4} / \mathrm{g}$ s to $0.4 \mathrm{~m}^{4} / \mathrm{g} \mathrm{s}$. Table 3 shows the percentage fog flux difference from the base case for $a_{\mathrm{g}}$ values of $0.1 \mathrm{~m}^{4} / \mathrm{g} \mathrm{s}$ and $0.4 \mathrm{~m}^{4} / \mathrm{g} \mathrm{s}$. For $0.1 \mathrm{~m}^{4} / \mathrm{g} \mathrm{s}$ the fog lasts for $20 \mathrm{~min}$ less than the base case, grows to approximately the same height, and has a mean liquid water content about $25 \%$ greater than the base case. The total fluxes of $\mathrm{S}(\mathrm{VI}), \mathrm{H}_{2} \mathrm{O}_{2}$, and $\mathrm{N}(\mathrm{V})$ are approximately $20 \%$ less than the base case since both the fog duration and the liquid water flux are less.

Table 3 shows that for an $a_{g}$ value of $0.4 \mathrm{~m}^{4} / \mathrm{g}$ s the water droplet flux increases by $6 \%$ of the base case. For $0.4 \mathrm{~m}^{4} / \mathrm{g} \mathrm{s}$ the fog lasts about $30 \mathrm{~min}$ longer than the base case and has a mean liquid water content that is $15 \%$ less than the base case value. The chemical species fog fluxes increase by approximately $20 \%$ due to greater fog droplet settling velocities. Although the greater $a_{g}$ value generally results in a lower liquid water content, the droplets are more concentrated and the result is an increase in chemical species fluxes. Model results suggest that the settling velocity parameterization introduces uncertainties of roughly $20 \%$ in the estimated fog fluxes.

\section{Relative Humidity Profile}

We assumed for our base case simulations that the initial $\mathrm{RH}$ profile $\left(\mathrm{RH}_{\mathrm{i}}\right)$ is constant at 0.88 for the $400-\mathrm{m}$ fog model domain. The assumption was necessary since $\mathrm{RH}$ profile

Table 3. Modeled Fog Flux Sensitivities to $a_{g}, \mathrm{RH}_{\mathrm{i}}$, and $a_{w}$

\begin{tabular}{|c|c|c|c|c|c|c|}
\hline & \multicolumn{6}{|c|}{ Modeled Fog Flux Sensitivites to $a_{g} \mathrm{RH}_{\mathrm{i}}$, and $a_{w}$} \\
\hline & \multicolumn{2}{|c|}{$\begin{array}{c}\text { Percentage Fog Flux } \\
\text { Difference From } \\
\text { Base Case }\left(a_{g}=0.2\right)\end{array}$} & \multicolumn{2}{|c|}{$\begin{array}{c}\text { Percentage Fog Flux } \\
\text { Difference From } \\
\text { Base Case }\left(\mathrm{RH}_{\mathrm{i}}=\mathbf{0 . 8 8}\right)\end{array}$} & \multicolumn{2}{|c|}{$\begin{array}{c}\text { Percentage Fog Flux } \\
\text { Difference From } \\
\text { Base Case }\left(a_{w}=0.01\right)\end{array}$} \\
\hline & $a_{g}=0.1$ & $a_{g}=0.4$ & $\mathrm{RH}_{\mathrm{i}}=\mathbf{0 . 8 0}$ & $\mathrm{RH}_{\mathrm{i}}=0.95$ & $a_{w}=0.0001$ & $a_{w}=0.1$ \\
\hline S(VI) & -24 & 21 & -40 & 17 & 0.5 & -0.4 \\
\hline $\mathrm{N}(\mathrm{V})$ & -24 & 16 & -39 & 35 & 31 & -3 \\
\hline $\mathrm{H}_{2} \mathrm{O}_{2}$ & -20 & 23 & -34 & 17 & 26 & -1 \\
\hline Fog water, $\mathrm{g} / \mathrm{m}^{2}$ & -6 & 6 & -44 & 34 & & \\
\hline
\end{tabular}




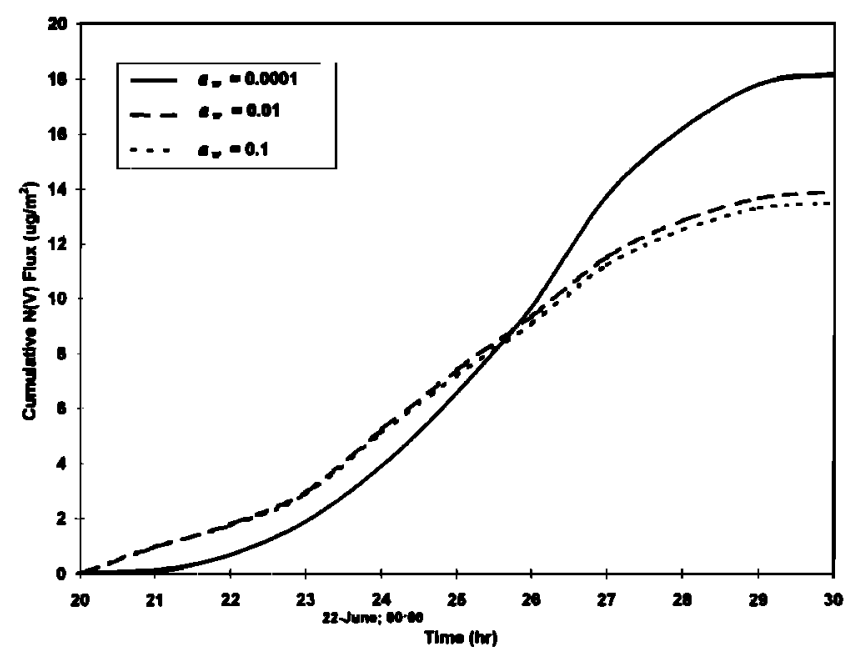

Figure 7. Predicted cumulative N(V) fluxes for $a_{w}$ values of $0.0001,0.01$, and 0.1 .

measurements are not available for Summit. Table 3 shows the sensitivity of the fog model to $\mathrm{RH}_{\mathrm{i}}$ values. When $\mathrm{RH}_{\mathrm{i}}$ is 0.95 the fog grows to approximately the same height as the base case, with the same duration and a mean LWC about $30 \%$ greater. The liquid water flux is $34 \%$ greater than the base case, and the fluxes of $\mathrm{S}(\mathrm{VI})$ and $\mathrm{H}_{2} \mathrm{O}_{2}$ are $17 \%$ greater, with the N(V) flux being $35 \%$ greater. The results in Table 3 generally show that the chemical and fog water fluxes are sensitive to the initial relative humidity profile and that for a wide range of initial relative humidities the chemical species fluxes are generally within $40 \%$ of the base case. The sensitivity of the model to the $\mathrm{RH}$ profile points out the importance of measuring this parameter at Summit.

\section{Accommodation Coefficient}

We have assumed so far that the accommodation coefficient, $a_{w}$, for all gas phase chemical species is 0.01 [Pandis and Seinfeld, 1989b]. This is due to the lack of experimental data available on the accommodation coefficients of chemical species for the low temperatures observed in Greenland. Worsnop et al. [1989] report $a_{w}$ values for $\mathrm{SO}_{2}$ and $\mathrm{H}_{2} \mathrm{O}_{2}$ at $273 \mathrm{~K}$ of roughly 0.20. Van Doren et al. [1990] report that $a_{w}$ for $\mathrm{HNO}_{3}$ decreases from about 0.2 at $293 \mathrm{~K}$ to 0.07 at $268 \mathrm{~K}$. Table 3 shows the sensitivity of the fog fluxes to the accommodation coefficient. We have chosen a lower limit accommodation coefficient value of 0.0001 , and an upper limit value of 0.1 . Table 3 shows that decreasing $a_{w}$ increases the fluxes of $\mathrm{N}(\mathrm{V})$ and $\mathrm{H}_{2} \mathrm{O}_{2}$. This is apparently counterintuitive, since one expects that decreasing the frequency at which molecules of $\mathrm{HNO}_{3}$ and $\mathrm{H}_{2} \mathrm{O}_{2}$ stick to the surface of droplets decreases the aqueous phase concentrations. The flux increases occur since the decrease in $a_{w}$ also results in slower aqueous phase uptake of $\mathrm{HO}_{2}$ and therefore relatively greater gas phase concentrations of both $\mathrm{HO}_{2}$ and $\mathrm{OH}$. This results in an increase in gas phase $\mathrm{HNO}_{3}$ production due to (R1). This agrees with model results presented by Schwartz [1984]. The $\mathrm{H}_{2} \mathrm{O}_{2}$ gas phase concentrations increase due to the reaction of $2 \mathrm{HO}_{2}$ molecules to form $\mathrm{H}_{2} \mathrm{O}_{2}$. The gas phase chemical species are eventually transferred to the aqueous phase, despite the much greater base case $a_{w}$ value. The result is that the droplets are initially less concentrated with respect to $\mathrm{HNO}_{3}$ and $\mathrm{H}_{2} \mathrm{O}_{2}$ and eventually become more concentrated towards the middle of the fog event. Figure 7 illustrates this point, by presenting the $\mathrm{N}(\mathrm{V})$ flux for values of $a_{w}$ ranging from 0.0001 to 0.1 . Figure 7 shows that for an $a_{w}$ of 0.0001 the cumulative flux for the first several hours of the fog is less than for the base case and eventually surpasses the base case flux as the droplets become more concentrated. Figure 7 shows that for $a_{w}$ values greater than 0.01 the $N(V)$ flux is relatively unchanged since the mass transport rate is unaffected by increases in $a_{w}$ after this point [Schwartz, 1984]. The flux of $\mathrm{SO}_{2}$ is relatively unaffected by changes in $a_{w}$ since the concentration of S(VI) in the aqueous phase is independent of changes in atmospheric $\mathrm{OH}$ and $\mathrm{HO}_{2}$.

As $a_{w}$ decreases below 0.0001 , the fog fluxes of S(VI) and $\mathrm{N}(\mathrm{V})$ begin to decrease since the mass transport of gases to the droplet surfaces becomes increasingly small. As $a_{w}$ approaches zero the flux of gases also goes to zero [Pandis and Seinfeld, 1989b]. It is difficult to assess the validity of the lower limit $a_{w}$ value of 0.0001 , since measurements of organic species in fogs have not been made at Summit.

\section{Impact of Fog Model Results on Ice Core Interpretation}

The deposition of aerosols and gases with fog can significantly influence the summer surface snow chemical composition at Summit [Bergin et al., 1994; Dibb et al, 1994]. The relative contributions of fog to the 1993 summer inventories of S(VI) and N(V) are approximately $30 \%$ and $10 \%$, respectively [Bergin et al., 1995b]. Unfortunately, the contribution of fogs to the annual chemical species fluxes has not yet been estimated, since field campaigns have not taken place during the winter. Observations reported from Dye 3 central Greenland show that the frequency of fogs generally increases during the winter months [Bergin et al., 1994], although this lower latitude sight is closer to the coast and may be more influenced by advective fogs than Summit.

To estimate the contributions of fog deposition to annual chemical signals it is necessary to know not only the frequency of fog events throughout the year but also the atmospheric concentrations of the gases and aerosols present during the fogs. If we assume that fog significantly influences the annual fluxes of various chemical species at Summit, the model results suggest that the relationship between the atmospheric gas phase concentrations and the deposition of chemical species with fog is complicated by the fact that several gas phase species can contribute to a single surface snow chemical signal. Model results show that the $N(V)$ fog flux is sensitive to the initial concentrations of $\mathrm{NO}_{2}, \mathrm{PAN}$, and $\mathrm{HNO}_{3}$. Results also suggest that both aerosol sulfate and gas phase $\mathrm{SO}_{2}$ contribute to the deposition of $\mathrm{S}(\mathrm{VI})$ with fog, although it is likely that $\mathrm{SO}_{2}$ typically contributes to roughly $30 \%$ or less of the S(VI) fog flux. Current measurements of 
$\mathrm{SO}_{2}$ have a great deal of uncertainty making it difficult to accurately assess the role of $\mathrm{SO}_{2}$ on $\mathrm{S}(\mathrm{VI})$ fog flux. Similarly, measurements of PAN, $\mathrm{NO}_{2}$, and other organic nitrates that may contribute to the fog N(V) flux have not been directly measured at Summit. It is possible that the relative concentrations of the gas phase species changes throughout the year. For instance, Bottenheim et al. [1994] show that PAN concentrations in eastem Canada are significantly higher in the winter than in the summer. This suggests that the aqueous phase formation of $\mathrm{N}(\mathrm{V})$ by PAN may be important during winter months. It is also possible that nighttime chemistry plays a role in creating $\mathrm{N}(\mathrm{V})$ from $\mathrm{NO}_{2}$ during the winter. Since dry deposition is negligible compared to the fog fluxes of chemical species during a fog event [Bergin et al., 1994], we have ignored the impact of dry deposition on snow chemistry. It is possible that dry deposition of gas phase chemical species affects the annual chemical signals, although the lack of atmospheric concentration measurements makes it extremely difficult to estimate the annual contribution of dry deposition to surface snow chemical signals. It is important to note that snow crystals may contain a quasi-liquid layer [Conklin and Bales, 1993] and it is therefore possible that similar chemistry observed during fogs occurs in clouds and in deposited surface snow. Overall, the model results suggest that estimates of past atmospheric chemistry of $N(V)$ and S(VI) based on ice core chemistry should consider the direct and indirect contributions of various gas phase chemical species. This is particularly clear for N(V) fog deposition, which depends on the relative atmospheric concentrations of $\mathrm{NO}_{2}, \mathrm{HNO}_{3}$, and PAN.

\section{Conclusions}

A Lagrangian model originally developed by Pandis and Seinfeld [1989a] to predict the fluxes of acidic species during fog events in Southern California has been modified and applied to a fog event at Summit, Greenland. The model is used to predict the evolution of the atmospheric LWC profile during a radiation fog, as well as detailed gas and aqueous phase chemistry, and the deposition of chemical species that include $\mathrm{S}(\mathrm{VI}), \mathrm{N}(\mathrm{V})$, and $\mathrm{H}_{2} \mathrm{O}_{2}$. The model is also used to assess the contribution of various gas phase species to the deposition of S(VI) and N(V).

The observed and predicted temperature profiles during the fog event are in close agreement. This indicates that the model adequately accounts for the transport of heat in the atmosphere, and at the air/snow interface. The ability of the model to follow dynamic changes in atmospheric temperature suggests that the transport of water vapor, and fog formation, is correctly modeled.

The atmospheric concentrations of $\mathrm{HCOOH}$ and $\mathrm{H}_{2} \mathrm{O}_{2}$ during the fog event generally agree with measurements. Comparison between the modeled and the measured $\mathrm{HNO}_{3}$ concentrations suggests that the mist chamber probably measures additional $\mathrm{NO}_{\mathrm{y}}$ species. The model underestimates the $\mathrm{SO}_{2}$ concentrations during fog. This may be due to uncertainties in the measured values.
The fluxes of liquid water, $\mathrm{S}(\mathrm{VI}), \mathrm{N}(\mathrm{V})$, and $\mathrm{H}_{2} \mathrm{O}_{2}$ with fog generally agree with measured values. Model results estimate that heterogeneous $\mathrm{SO}_{2}$ oxidation by $\mathrm{H}_{2} \mathrm{O}_{2}$ contributes to approximately $40 \%$ of the S(VI) flux during the fog event, with the remaining $60 \%$ coming from the preexisting sulfate aerosol. Although direct measurements of $\mathrm{PAN}$ and $\mathrm{NO}_{2}$ are not available for the fog event, model results based on likely atmospheric concentrations of these species indicate that they may significantly contribute to the deposition of N(V) with fog. Furthermore, if a quasi-liquid layer indeed exists on the surface snow at Summit, similar reactions occurring in fog droplets may also influence snow chemistry.

The fog droplet settling velocity parameter, $a_{g}$, as well as the initial relative humidity profile, $\mathrm{RH}_{1}$, significantly influence the fluxes of chemical species with fog. For the likely range of values for $a_{g}$ and $\mathrm{RH}_{\mathrm{i}}$ the fog fluxes vary by $20 \%$ and $30 \%$, respectively. Also, the fog fluxes of $N(V)$ and $\mathrm{H}_{2} \mathrm{O}_{2}$ increase by roughly $30 \%$ as the accommodation coefficient is decreased from 0.01 to 0.0001 . This is due to increased gas phase $\mathrm{HNO}_{3}$ production at lower $a_{w}$ values due to a decrease in the partitioning of $\mathrm{HO}_{2}$ in the aqueous phase.

Model results suggest that accurate measurements of $\mathrm{SO}_{2}$, $\mathrm{NO}_{2}, \mathrm{HNO}_{3}$, and PAN are needed to accurately estimate the flux of S(VI) and N(V) during fogs at Summit. Also, measurements of the initial prefog relative humidity profiles are needed, since the chemical species fluxes with fog are relatively sensitive to this parameter.

Model results suggest that it is important to quantify the frequency and chemical composition of fog events throughout the year at Summit so that the direct contribution of fogs to annual chemical signals can be determined. It is also necessary to measure the atmospheric concentrations of the gas phase chemical species contributing to S(VI) and N(V) fog deposition so that the chemistry associated with fog deposition can be better understood. It is important to point out that similar chemistry observed during fogs may occur in ice crystals in clouds as well as in deposited surface snow. Model results generally suggest that estimates of past atmospheric chemistry of $N(V)$ and $S(V I)$ based on ice core chemistry may need to consider the direct and indirect contributions of various gas phase chemical species.

Acknowledgments. We would like to thank Sally Whitlow for advice concerning the IC analyses. We also thank Mark Losleben and Roger Bales for measuring $\mathrm{H}_{2} \mathrm{O}_{2}$ in the air and in fog samples. This work was supported by NSF grants DPP-9123082, OPP-9321642, OPP-9423410, ATM-9508051, and EC grant TAGGSI EV5V-0412.

\section{References}

Albert, M.R., and W.R. McGilvary, Thermal effects due to air flow and vapor transport in dry snow, J. Glaciol., 38, 1992.

Atkinson, R., A. Lloyd, Evaluation of kinetic and mechanistic data for modeling photochemical smog, J. Phys. Ref. Chem. Data, 13, 315444, 1984.

Bales R.C., M.V. Losleben, J.R. McConnell, K. Fuhrer, and A. Neftel, $\mathrm{H}_{2} \mathrm{O}_{2}$ in snow, air, and open pore space in firn at Summit, Greenland, Geophy Res. Let., 22(10), 1261-1264, 1995 a. 
Bales, R., J.R. McConnel, M.V. Losleben, M.H. Conklin, K. Fuhrer, A. Neftel, J.E. Dibb, J.D.W. Kahl, and C. Stearns, The Diel variations of $\mathrm{H}_{2} \mathrm{O}_{2}$ in Greenland: $A$ discussion of the cause and effect relationship, J. Geophys. Res., 100,18,661-18,668, $1995 \mathrm{~b}$.

Bergin, M.H., J.L. Jaffrezo, C.I. Davidson, R. Caldow, and J.E. Dibb, Fluxes of chemical species to the Greenland lce Sheet at Summit by fog and dry deposition, Geochem. Cosmochim. Acta, 58(15), 3207-3215, 1994.

Bergin, M.H., C.I. Davidson, J.L. Jaffrezo, J.E. Dibb, R. Hillamo, H.D. Kuhns, and T. Makela, The contributions of wet, fog, and dry deposition to the summer flux of $\mathrm{SO}_{4}{ }^{2-}$ at Summit, Greenland, In Ice Core Studies of Global Biogeochemical Cycles, edited by $\mathbf{R}$. Delmas, NATO-ASI Ser., Vol. 30, pp 121-138, Springer-Verlag. New York, 1995a.

Bergin, M.H., J. L. Jaffrezo, C.I. Davidson, J.E. Dibb, S.N. Pandis, R. Hillamo, W. Maenhaut, H.D. Kuhns, and T. Makela, The contributions of snow, fog, and dry deposition to the summer flux of anions and cations at Summit, Greenland, J. Geophys. Res., $100,16,275-16,288,1995 b$.

Bergin, M.H., C.I. Davidson, J.E. Dibb, J. L. Jaffrezo, H.D. Kuhns, and S.N. Pandis, A simple model to estimate atmospheric concentrations of aerosol chemical species based on snow core chemistry at Summit, Greenland, Geophy. Res. Lett., 22(24), 3517-3520, 1995c.

Borys, R.D., D. Del Vecchio, J.L. Jaffrezo, J.E. Dibb, and D.L. Mitchell, Field observations, measurements and preliminary results from a study of wet deposition processes influencing snow and ice chemistry at Summit, Greenland, in Precipitation, Scavenging and Atmospheric Surface Exchange, edited by S.E. Schwartz and W.G.N. Slinn, Vol. 3, pp.1693-1702, Hemisphere Publ. Corp., Philadelphia, 1992.

Bottenheim, J.W., A. Sirois, K.A. Brice, and A.J. Gallant, Five years of continuous observations of PAN and ozone at a rural location in eastern Canada, J. Geophys. Res., 99, 5333-5352, 1994.

Brown, R., and Roach, W.T., The physics of radiation fog, II, A numerical study, Q.J.R. Meleorol. Soc., I02, 335-354, 1976.

Carter, W.P.L., and R. Atkinson, Development and implementation of an up-to-date photochemical mechanism for use in airshed models, summary and final report, Calif. Air Resour. Board, Sacramento, 1988.

Conklin, M.H., and $\mathrm{R}$. Bales, $\mathrm{SO}_{2}$ uptake on ice spheres: liquid nature of the ice-air interface, J. Geophys. Res., 98, 16,851-16,855, 1993.

Dansgaard, W. et al., Evidence for general instability of past climate from a 250-kyr ice-core record, Nature, 364, 218-220, 1993.

Daum, P.H., S.E. Schwartz, and L. Newman, Studies of the gas and aqueous-phase composition of stratoform clouds, in Precipitation, Scavenging, Dry Deposition, and Resuspension, edited by H.R Pruppacher, R.G. Semonin, and W.G.N. Slinn, pp. 31-52, Elsevier, New York, vol. 1, 1983.

Davidson, C.I., M.H. Bergin, and H.D. Kuhns, Atmospheric deposition of chemical species to polar snow, Chem. Eng. Commun., in press, 1996.

Dibb, J.E., Overview of field data on the deposition of aerosolassociated species to the surface snow of polar glaciers (emphasizing recent work in Greenland), Processes of Chemical Exchange between the Atmosphere and Polar Snow, NATO ASI Ser., Brussels, in press, 1996.

Dibb, J.E., R.W. Talbot, and M.H. Bergin, Soluble acidic species at Summit, Greenland, Geophy. Res. Lett., 21(15), 1627-1630, 1994.

Fan, S.-M., D.J. Jacob, D.L. Mauzerall, J.D. Bradshaw, S.T. Sandholm, D.R. Blake, H.B. Singh, R.W. Talbot, G.L. Gregory, and G.W. Sachse, Origin of tropospheric $\mathrm{NO}_{\mathrm{x}}$ over subarctic eastern Canada in summer, J. Geophys. Res., 99, 16,867-16,877, 1994.

Fuzzi, S., G. Orsi, G. Nardini, M.C. Facchini, S. McLaren, E. McLaren, and M. Mariotti, Heterogeneous processes in the Po valley radiation fog, J. Geophys. Res., 93, 11,141-11,151, 1988.

Gill, P.S., G. Graedel, and C.J. Weschler, Organic films on atmospheric aerosol particles, fog droplets, cloud droplets, raindrops, and snowflakes, Rev. Geophys., 21, 903-920, 1983.

Jacob, D.J., et al., Summertime photochemistry of the troposphere at high northern latitudes, J. Geophys. Res., 97, 16,421-16,432, 1992.
Jaffrezo, J.L., J.E. Dibb, R.C. Bales, and A. Neftel, Current status of atmospheric studies as Summit (Greenland) and implications for future research, Ice Core Studies of Global Biogeochemical Cycles, edited by R.Delmas, NATO-ASI Ser., vol. 30 pp 427-458, Springer-Verlag, New York, 1995.

Lee, Y.-N., Atmospheric aqueous phase reactions of nitrogen species, gas-liquid chemistry of natural waters, BNL Rep. 51757, vol. 1, pp. 20/1-20/10, Brookhaven Natl. Lab., 1984.

Legrand, M., and M. DeAngelis, Origins and variations of light carboxylic acids in polar precipitation, J. Geophys. Res., 100, 1445-1462, 1995.

Mayewski, P.A., W.B. Lyons, M.J. Spencer, M.S. Twickler, C.F. Buck, and S. Whitlow, An ice-core record of atmospheric response to anthropogenic sulphate and nitrate, Nature, 346, 554-556, 1990.

Mayewski, P.A., et al., Record drilling depth struck in Greenland. EaS Trans., 75(7), 113, 1994.

McDonald, J.E., The saturation adjustment in numerical modeling of fog, J. Atmos. Sci., 20, 476-478, 1963.

McRae, G.J., W.R. Goodin, and J.H. Seinfeld, Development of a second generation mathematical model for urban air pollution, I. Model formulation, Atmos. Environ., 16, 679-696, 1982.

Munger, J.W., J. Collett, B. Daube, and M. Hoffmann, Fogwater chemistry at Riverside, California, Atmos. Environ., 24B, 182-205, 1990.

Muthuramu, K., P.B. Shepson, J.W. Bottenheim, B.T. Jobson, H. Niki, and $H$. Anlauf, Relationships between organic nitrates and surface ozone destruction during Polar Sunrise Experiment 1992, J. Geophys. Res., 99, 25,369-25,378, 1995.

Noone K.J., J.A. Ogren, K. Birgitta Noone, A. Hallberg, S. Fuzzi, and J.A. Lind, Measurements of the partitioning of hydrogen peroxide in a stratifrom cloud, Tellus, 43B, 280-290, 1991 .

Noone, K.J., et al., Changes in aerosol size-and phase distributions due to physical and chemical processes in fog, Tellus, 44B, 489504, 1992.

Pandis, S.N., and J.H. Seinfeld, Mathematical modeling of acid deposition due to radiation fog, J. Geophys. Res., 94, 12,911$12,923,1989$ a.

Pandis, S.N., and J.H. Seinfeld, Sensitivity analysis of a chemical mechanism for aqueous-phase atmospheric chemistry, J. Geophys. Res., 94, 1105-1126, 1989b.

Russel, A.G., G.R. Cass, and J.H. Seinfeld, On some aspects of nighttime atmospheric chemistry, Environ. Sci. Technol, 20, 1167 $1172,1986$.

Saltzman, E.S., D.L. Savoie, R.G. Zika, and J.M. Prospero, Methane sulfonic acid in the marine atmosphere, J. Geophys. Res., 88, $10,897-10,902,1983$.

Sandholm, S.T., et al., Summertime troposphericobservations related to $\mathrm{N}_{\mathrm{x}} \mathrm{O}_{\mathrm{y}}$ distributions and partitioning over Alaska: Arctic Boundary Layer Expedition 3A, J. Geophys. Res., 97, 16,481$16,509,1992$.

Schwartz, S.E., Gas and aqueous-phase chemistry of $\mathrm{HO}_{2}$ in liquid water clouds, J. Geoplyys. Res., 89, 11,589-11,598, 1984.

Shir, C.C., A preliminary study of atmospheric turbulent flows in the idealized planetary boundary layer, J. Atmos. Sci., 30, 1327-1339, 1973.

Silvente, E., and M. Legrand, A preliminary study of the air-snow relationship for nitric acid in Greenland, Ice Core Studies of Global Biogeochemical Cycles, edited by R. Delmas, NATO-ASI Ser., vol. 30, pp 225-240, Springer-Verlag, New York, 1995.

Singh, H.B., D. O'Hara, D. Herlth, J.D. Bradshaw, S.T. Sandholm, G.L. Gregory, G.W. Sachse, D.R. Blake, P.J. Crutzen, and M.A. Kanakidou, Atmospheric measurements of peroxyacetyl nitrate and other organic nitrates at high latitudes: Possible sources and sinks, J. Geophys. Res., 97, 16,511-16,522, 1992.

Thompson, A.M., et al., Ozone observations and a model of maripe boundary layer photochemistry during SAGA 3, J. Geoplnys., Res. 98, 16,955-16,968, 1993.

Turton, J.D., and R. Brown, A comparison of a numerical method of radiation fog with detailed observations, $Q . J . R$. Meteorol. Soc. 113, 37-54, 1987.

Van Doren, J.M., L.R. Watson, P. Davidovit, D.R. Worsnop, M.S. Zahniser, C.E. Kolb, Temperature dependence of the uptake 
coefficients of $\mathrm{HNO}_{3}, \mathrm{HCl}$, and $\mathrm{N}_{2} \mathrm{O}_{5}$ by water droplets, J. Phys. Chem. 94, 3265-3269, 1990.

Winiwarter, W., et al., Henry's law and the behavoir of weak acids and bases in fog and cloud, J. Atmos. Chem., 19, 173-188, 1994.

Worsnop, D.R., M.S. Zahniser, C.E. Kolb, J.A. Gardner, L.R. Watson, J.M. Van Doren, J.T. Jayne, P. Davidovits, Temperature dependence of mass accommodation of $\mathrm{SO}_{2}$ and $\mathrm{H}_{2} \mathrm{O}_{2}$ on aqueous surfaces, J. Phys. Chem, 93, 1159-1172, 1989.

Zdunkowski, W.G., W.-G. Panhans, R.M. Welch, andG.J. Korb, A radiation scheme for circulation and climate models, Beitr. Phys. Atmos., 55, 215-238, 1982.

M. H. Bergin, NOAA, R/E/CG1, 325 Broadway, Boulder, CO 80303. (mbergin@cmdl.noaa.gov)

S.N. Pandis, Department of Chemical Engineering, Carnegie Mellon University, PGH, PA 15213. (spyros@andrew.cmu.edu)

C.I. Davidson, Department of Civil and Environmental Engineering, Carnegie Mellon University, PGH, PA 15213. (cdow@andrew.cmu.edu)
J.-L. Jaffrezo, LGGE du CRNS, Domaine Universitaire, Rue Molicre, BP96, 38402, Saint Martin, d'Héres, France. (jlj@glaciog.grenet.fr)

J.E. Dibb, IEOS, University of New Hampshire, Durham, N.H. 03824. (jed@unh.edu)

AG. Russell, School of Civil and Environmental Engineering. Georgia Institute of Technology, Atlanta, GA 30332-0512. (trussell@ce.gatech.edu)

H.D. Kuhns, Department of Civil and Environmental Engineering Carnegie Mellon University, PGH, PA 15213. (hk26@andrew.cmu.edu)

(Received May 31, 1995; revised January 13, 1996;

accepted January 13, 1996.) 